\title{
Methods for Determining Agitator Mixing Requirements for a Mixing \& Sampling Facility to feed WTP
}

\author{
P.W. Griffin
}

Washington River Protection Solutions, LLC

Richland, WA 99352

U.S. Department of Energy Contract DE-AC27-08RV14800

\author{
EDT/ECN: DRF UC: \\ Cost Center. Charge Code: \\ B\&R Code: $\quad$ Total Pages: 45
}

Key Words: Mechanical mixer, Mixing and Sampling Facility, Zwietering correlation, suspension, high level waste mixing.

Abstract The following report is a summary of work conducted to evaluate the ability of existing correlative techniques and alternative methods to accurately estimate impeller speed and power requirements for mechanical mixers proposed for use in a mixing and sampling facility (MSF). The proposed facility would accept high level waste sludges from Hanford double-shell tanks and feed unifonmly mixed high level waste to the Waste Treatment Plant. Numerous methods are evaluated and discussed, and resuling recommendations provided.

TRADEMARK DISCLAIMER. Reterence herein to any specific commercial product, procosos, or tervice by trade norie, tradtemark, manufacturer, or otherwise, does not necpssarily constitute or imply its endorsernont, recomrnendation, or faworing by the United states Govemment of any agency thereol or ins contractors or subcontractars.

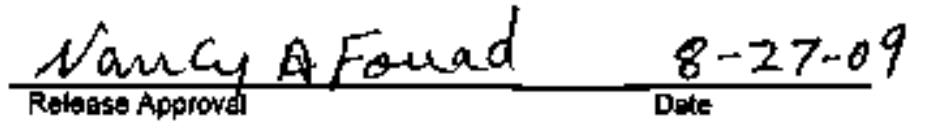

Approved For Public Release

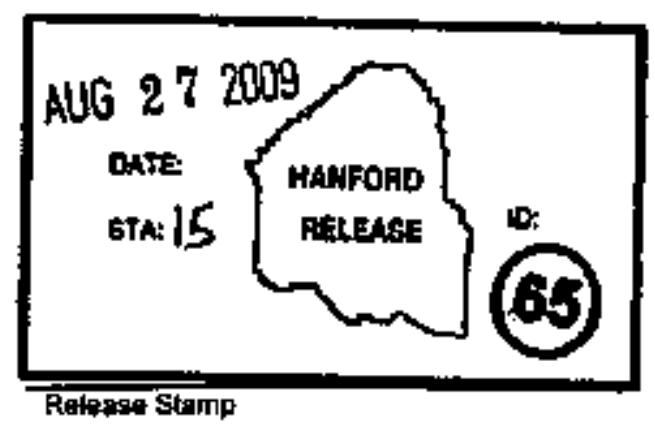




\section{Methods for Determining Agitator Mixing Requirements for a Mixing \& Sampling Facility to feed WTP}

P.W. Griffin

Washington River Protection Solutions, LLC

August, 2009

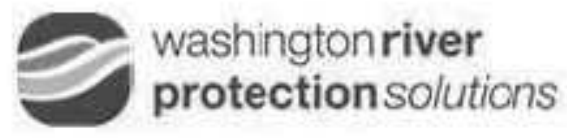

P.O. Box 850

Richland, WA 99352 


\section{EXECUTIVE SUMMARY}

The following report is a summary of work conducted to evaluate the ability of existing correlative technicjues and alternative methods to accurately estimate impeller speed and power requirements for nechanical mixers proposed for use in a miximg and sampling facility (MSF). The proposed facility would accept high level waste (HLW) sludges from Hanford double-shell tanks (DST) and feed uniformly mixed HLW sludge to the Waste Treatment Plant (WTP). Numerous methods are evaluated and discussed, and resulting recommendations provided. Due to the complexity of the task and the lack of available, applicable correlations and tecluniques, the final recommendation is to consult professional mixing personnel for the purpose of developing a scaled model test plan to detemine systen requirenents. The consultant nust have notable experience developing mixing systems that process broad particle size and density distributions, ideally in the nuclear industry. One such consultant considered in this report is Philadelphia Mixing Solutions, Ltd. (PMSL). PMSL has extensive experience designing mixing systems for the nuclear industry with successful product deliveries currently in use at Savannah River Site, Oak Ridge, and IHI in Japan. They are the NQA-1 eertified supplier of mechanical mixers for the WTP Project managed by Bechtel National Inc..

Calculations contained herein are preliminary and served to guide the problem of sizing mechanical misers for mixing Hanford tank HLW sludge toward a nore empirical approach to determine proper mixer sizing configuration. Note also that the industry aceepted approach is to use scaled nodel testing to determine proper nuxer sizing for complex applications, not generalized correlations. Further, the risk to the WFD Project resulting from incorrect calculations is low due to the very low probability that incorrect conclusions were drawn from these calculations. While the preliminary calculations contained herein do not fit the definition of "computation" per TFC-ENG-DESIGN-C-10 (thus requiring no documented calculation check), it was determined that little value would be added by performing a calculation check commensurate with an informal calculation. Users nust recognize this limitation and engage in calculation verification as per TFC-ENG-DESIGN-C-10 if results from calculations are used explicitly. 


\section{TABLE OF CONTENTS}

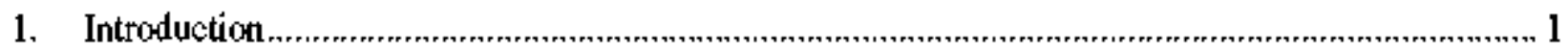

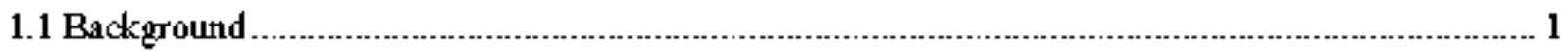

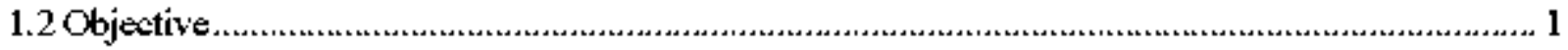

1.3 Overview of MSF Requirements ......................................................................................... 2

1.4 An Introduction to Mechanically Agitated Mixing Systems ….................................................... 2

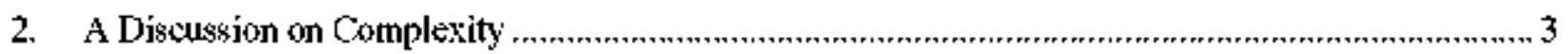

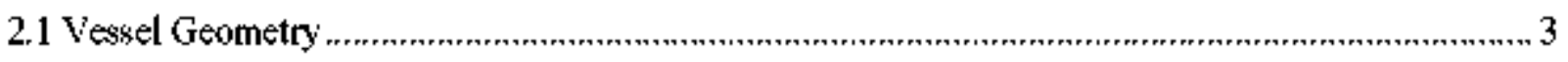

2.2 Impellet

2.3 Process Constituents and Process Requirements ................................................................... 4

3. Analytical Techniques - The Zwietering Correlation .................................................................. 5

3.1 Appliwation of The Zwietering Cortelation ................................................................................... 5

3.2 Comments on Applying Zwieteling's Cotrelation............................................................. 7

3.3 Zwietering Results ............................................................................................... 9

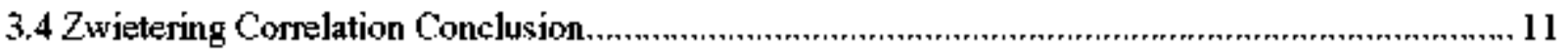

4. Analytical Techricjues -- The Okdshue Technique............................................................ 11

4.1 The Oklshue Technique.................................................................................................. 11

4.2 APPLYING THE OLDSHUE TECHNIQUE............................................................ 11

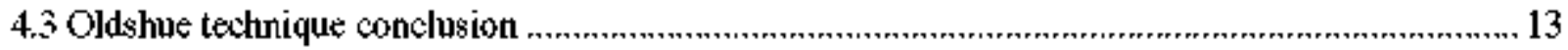

5. Analytical Techniques -- Modified Froude Number Cortelation ....................................................... 14

6. Conclusion on Cortelative Teshniques ............................................................................ 14

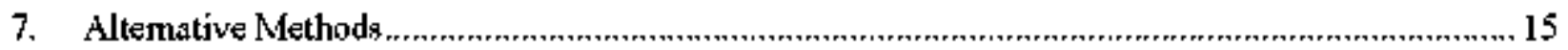

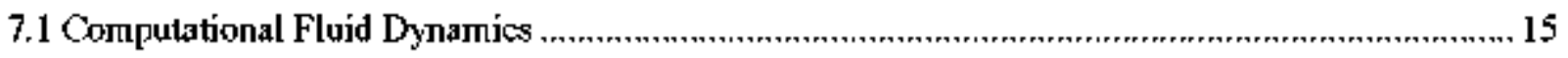

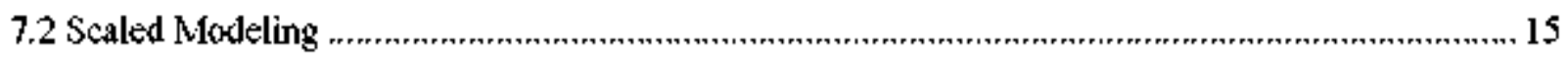

7.3 Expert Appeal - Philadelphia Mixers ..................................................................... 16

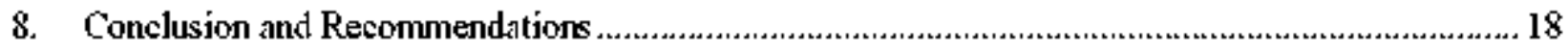

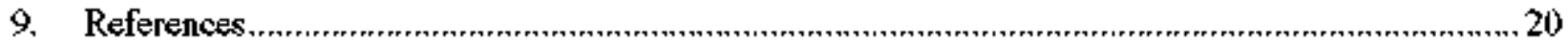

\section{LIST OF APPENDIXES}

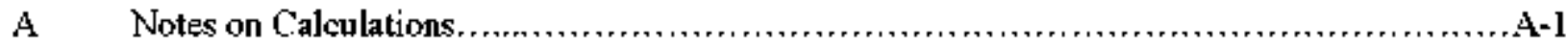

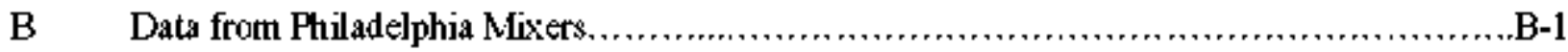

C Unpublished Reference Material................................................ 


\section{LIST OF FIGIRES}

Figure 1-1. Standard mechanically agitated vessel ....................................................................... 2

Figure 1-2. Degrees of suspension .............................................................................................. 3

Figure 6-1. Patameter ratnge comparison ............................................................................... 15

\section{LIST OF TABLES}

Table 3-1. Operating conditions over which the Zwietering correlation was obtained ........................ 7

Table 3-2. Best-recommendation waste property parameters of average $\mathrm{HL}$ W................................. 8

Table 3-3. Zwietering correlation results for 1 PBT4-45 impeller ................................................ 10

Table 3-4. Zwietering correlation results for 2 PBT4-45 impellers ................................................... 10

Table 4-1. Particle free-settling velocities ........................................................................ 12

Table 4-2. Power and impeller speed predictions ...................................................................... 13

Table 4-3. Power consumption based on Oldshue Technique ................................................... 13

Table 7-1. PSDD as utílized by Philadelphia Nixers …......................................................................... 17

Table 7-2. Philadelphia Mirers" recommended speed and power f......................................................... 17 


\section{ABBREVIATIONS AND ACRONYMS}

BR Best Recommendation

CFD Computational Fluid Dynamics

HLW High-level waste

MFN Modified Froude number

MSF Mixing and Sampling Facility

NQA Nuclear quality assurance

PBT Pitched-blade turbine

PBT4-45 4-blade pitched-b]ade turbine, blade angle $=45^{\circ}$

PMSL Philadelplia Mixing Solntions, Ltd.

PSDD Particle size and density distribution

WTP Waste Treatment Plan

\section{VARIABLES AND CONSTANTS}

B

C

sw

D

$\mathrm{d}_{\mathrm{p}}$

$\Delta \rho$

$\mathrm{g}$

$k$

$\mu_{\mathbf{L}}$

$\mathrm{N}$

$\mathbf{n}_{\mathrm{b}}$

$\mathrm{N}_{\mathrm{JS}}$

$\mathrm{N}_{\mathrm{U}}$

$\checkmark$

$P$

$P_{0}$

$P_{\text {O.E }}$

PO.H

PO.PBT

$\pi$

$\mathrm{R}$

PI

$p_{s}$

Baffle width

Impeller clearance from vessel base

Solids concentration percentage by weight

Inpeller diameter

particle diameter

Density difference $\left(\Delta \rho=\rho_{5}-\rho_{1}\right)$

Gravimetric constant $\left(g=9.81 \frac{\mathrm{m}}{\mathrm{s}^{2}}\right)$

Scale up equation constant

Liquid dynamic viscosity

Impeller speed

number of impeller blades

Agitator "just-suspended" speed

Agitator speed for uniform suspension

Liquid kinentatis viscosity

Power

Power number

Ejuivalent power number

Hydrofoil power number

Pitched-blade turbine power nunber

geonetrical constant, pi $(\pi=3.14 \ldots)$

regression line correlation coefficient

Liquid density

Solids density 
RPP-RPT-42527, Rev, 0

$\begin{array}{ll}\rho_{\text {slumy }} & \text { Slumy density } \\ \mathrm{s} & \text { Inpeller geonetry constant } \\ \mathrm{T} & \text { Vessel diameter } \\ \mathrm{Tq} & \text { Shaft Torque } \\ \mathrm{V}_{5} \text { or Vs } & \text { Setlling velocity } \\ \mathrm{v}_{\mathrm{s}} & \text { solids volune fraction } \\ \mathrm{W} & \text { Blade width } \\ \mathrm{X} & \text { Solid to licuid mass ratio } \\ \mathrm{Z} & \text { Liquid level height }\end{array}$

\section{MATHEMATICAL UNITS}

$\begin{array}{ll}\text { ftimin } & \text { feet per minute } \\ \mathrm{ft} & \text { foot } \\ \text { gal } & \text { gallons } \\ \mathrm{g} / \mathrm{mL} & \text { grams per milliliter } \\ \mathrm{HP} & \text { horse power } \\ \frac{\mathbf{k} g}{\mathbf{m}^{3}} & \text { kilograms per cubic meter } \\ \mathrm{m} & \text { meler } \\ \mu \mathrm{m} & \text { micron } \\ \mathrm{mm} & \text { millimeter } \\ \mathrm{mPas} & \text { millipascal-seconds } \\ \mathrm{ln} & \text { natural logarithm } \\ \mathrm{N} / \mathrm{n} / 2 & \text { Newton-seconds per square meter } \\ \mathrm{rpm} & \text { revolutions per minute } \\ \mathrm{rev} / \mathrm{s} & \text { revolutions per second } \\ \mathrm{m} 2 / \mathrm{s} & \text { square meters per second }\end{array}$




\section{INTRODUCTION}

\subsection{BAC'KGROUND}

When stored over time, Hanford tank waste segregates into various phases it at attempt to reach equilibrium. These phases are known as supentatant, saltcake, and sludge, and exist in varying concentratious in mosi tanks. Supematant refers to waste that exists as a liquid, generally floating above any solid matter. Saltcake is comprised of chemicals which have crystallized to form solids. Finally, insoluble solids which have settled at the tank botlom comprise what is known as sludge. In the interest of mobilizing this waste for transfer to other tanks or the WTP, saltcake and sludge nust be mixed back into solution. With the help of hot water, saltcake can be remixed fairly easily. Sludge waste, on the other hand, poses a greater challenge. Because tank waste is removed by pumping, the sludge must be vigorously mixed to suspend it in a carrier fluid; pure solids cannot be pumped. Current plans for mixing DST sludges include mixing via jet mixer pumps. Jet mixer pumps offer a limited degree of mixing that may be quite acceptable for mobilizing and transferting waste, but possibly too srude a procedure to meet sone proposed receipt requirements of the WTP.

WTP has numerous requirements that all waste must satisfy prior to being received (ICD-19). To characterize and certify any waste intended for processing a sample must be taken and endure a testing period of more than 180 days. It is essential to safe and efficient operations that the sample is reptesentative of an entire tauk's contents, if possible. The nost dependable solntion is to provide mixing capability that yields a uniform sludge mixture. If a sample is taken incortectly or it is determined that the sample is not a valid representation of the tank waste, WTP will refuse the transfer until such a sample can be provided. It is, therefore, fundamental to the success of both the Tank Farms Contractor (TFC) and WTP that a method for reliable, representative sampling be developed and that waste transferred to the WTP be consistent with that sample.

One of the proposed solutions for ensuring that waste can be delivered in accordance with WTP waste acceptance criteria is a separate mixing and sampling facility. Such a facility would be dedicated to acopting HLW sludges from DSTs and developing conditions for reliable sampling and transter operations inmediately prior to transfer to the WTP. Currently, it is thought that unifom mixing of waste will be required to obtain a sufficiently reliable sample. While testing is currently planted to demonstrate the homogeneous mixing capability of existing jet nixer pumps in DSTs, a MSF is being considered as a contingency in the event that 1he demonstration proves unsuccessful. This facility would utilize an altemative mixing technology and be designed specifically to ensure proper mixing and sampling.

\subsection{OBJECTIVE}

This paper seeks to briefly evaluate several methods for determining speed and power requirenents for agitator-style mixers proposed for use in MSF and recommend best-suited 
method. Techniques, obstacles, and proposed future work will be discussed. In addition, estimates of functional requirements for the process mixing vessels including vessel geometry, agitation speed, and power consumption are provided.

\subsection{OVERVIEW OF MSF REQUIREMENTS}

For an initial estimation purposes, MSF will be considered to house six, 500,000 gallon tanks, each equipped with equivalent waste mixing and sampling capabilities. This estimate was arrived at by considering contingency support in the event that some batches would be unavailable for on-schedule transfer to WTP. WTP waste acceptance criteria mandates that HLW will be transferred in batches of up to 160,000 gallons (ICD-19).

\subsection{AN INTRODUCTION TO MECHANICALLY AGITATED SYSTEMS}

Mechanically agitated systems have long been used to facilitate mixing of innumerable sorts. Basically, a mechanically agitated vessel system consists of several key components. A vessel is needed in which the materials to be mixed can be confined An agitator, very often some form of a propeller or paddle, is placed within the vessel to stir the material and promote dispersion. Finally, a motor or some source of rotational energy is affixed to the agitator, often by a shaft. Figure 1-1, below, shows a standard mechanically agitated mixing system.

Figure 1-1. Standard mechanically agitated vessel (from mixingsolutions,com)

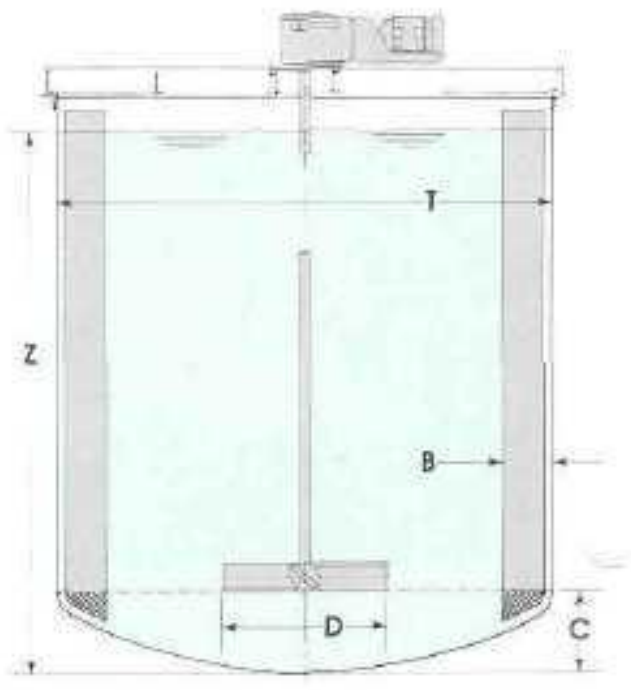

The degree, or quality, of solid suspension can be measured in several ways, but is most frequently classified into three categories: on-bottom motion, off-bottom suspension, and uniform suspension. Figure 1-2, below, is provided as a visual representation of each category. 
Figure 1-2. Degrees of suspension (modified from Edward et al. 2004)
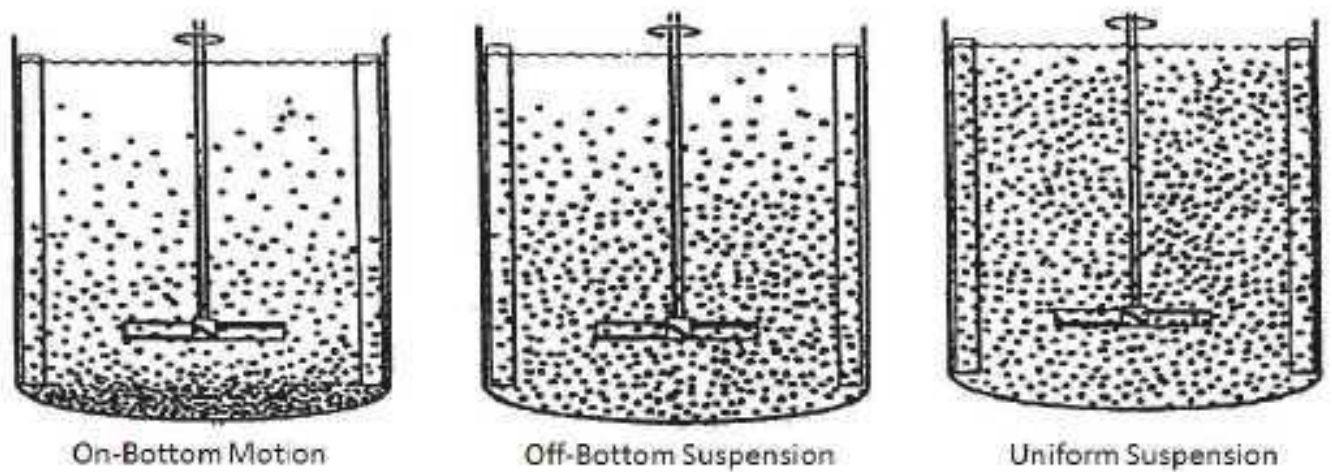

On-bottom motion describes the complete motion of solids particles on the bottom of the vessel. This is often achieved at very low levels of agitation where most solids constantly remain in contact with the vessel base. Off-bottom suspension refers to a state of agitation in which all particles exhibit complete motion, with no particle resting on the vessel base for longer than 1-2 seconds. Many correlations, originating with the work of Zwietering (discussed below) are concerned with the minimum agitator speed required to achieve this state. It is referred to as the "just-suspended" speed. Uniform suspension describes the state of suspension at which particle concentrations and distributions are nearly uniform throughout the vessel. A concentration gradient of $5 \%$ is considered adequate for most applications. Uniformity of $100 \%$ is nearly impossible, and at the very least often impractical and unnecessary, due to the existence of a thin fluid layer of lower particle concentration at the top of the fluid. Therefore, the term "uniform suspension" as used in this document will refer to a suspension of approximately $95 \%$ uniformity.

\section{A DISCUSSION ON COMPLEXITY}

It is often easy to underestimate the complexity of determining hardware requirements for mixing applications. The following section provides a brief discussion of aspects that must be sufficiently considered when developing such requirements.

\subsection{VESSEL GEOMETRY}

Mixing is dominated by fluid flow characteristics, and fluid flow, in turn, is a function heavily related to tank geometry. A poorly designed tank may never mix correctly no matter how fast the impeller spins.

Liquid level height and vessel diameter are two very important quantities. The liquid height to vessel diameter ratio $(Z / T)$ will determine the number of impellers required for various degrees of suspension. The impeller diameter to tank diameter ratio (D/T) will dictate other requirements 
such as agitation speed, power, and shaft torque. How the impeller(s) enters the vessel will determine nunerous other geometrical decisions. Top entering nixers on the tank centerlite often create a vortex effect which must be acoounted for by the installation of baffles. The number of baftles, their location, and dimensions all become key factors that will affect mixing. Slight variations in any of the geontetries may be the difference between exceptionally good mixing and none at all.

There is no one configuration of these parameters that will suit all applications. As process varjables change, tank geometry must clange to sujt them. One configuration may work exeeptionally well for a particular application but may be the worst configuration for another.

\subsection{IMPELLER}

Impeller selection is, while less enigmatic than tank geometry, another very important suspension-defiuing variable. Numerous impeller styles exist to serve different purposes. Selection is made fairly easy for suspending solids in low-viscosity fluids. A hydrofoil is a specific type of axial flow impeller which lends itself particularly well to solids suspension in low-viscosity fluids. It is more efficient than a pitch-blade turbine, requiring less power for a comparable suspension quality. Once the impeller is selected, the optimal speed that can achieve the desired level of suspension can be determined. Many techniques and methods have been developed attempting to correlate impeller speed with suspension, each with different constraints and linitations.

\subsection{PROCESS CONSTITUENTS AND PROCESS REQUIREMENTS}

The provess constituents, as related to this report, are defined as those materials which will undergo mixing. In this case, they are the liquid supernatant and solid sludge. The process reculirements are criteria that must be met by the nixing system. They involve qualifications for degree of suspension. process constituent envelope. batch size, and the like. The process constituents and process requirements dictate the design of the system.

Design difficulty is closely relaled to the nature of the process constituents. Complexity arises when oumerous constituents of varying densities, sizes, and concentrations are present. Several itenus that must be considered for system design are:

- Flow pattems induced by the tank geometry and impeller must be sufficient to meet process requirements

- Flow pattern changes as a result of variable process constituents must be considered

- Vessel design should be optimized to rechee motor power requirements

Numerous attempts have been made to predict mixing behavior by way of plissical testing. correlations, and computational fluid dynamics. While these methods work to some capacity, the overwhelming number of variables and unknown phenomena has prevented an aceurate 
mathematical representation for all configurations and under all circumstances. Correlations can be found, however, that provide reliable predictions over a nartow range of conditions.

A particular difficulty facing MSF is that not all HLW has teen characterized and therefore not all waste properties are known. This issue is further complicated by the fact that batch rheology and characteristies may change upon transfer fron the storage tanks to MSF tanks. Therefore. consideration mus1 be made in the design to accommodate unknown waste.

\section{ANALYTICAL TECHNIQUES - THE ZWIETERING CORRELATION}

Numerous studies and years of research have been devoted to developing methods for predicting mixing behavior and system requirements. Correlations, such as those presented in the following section, have been widely used to assist in the preliminary design of liquid-liquid and liquidsolid nixing systens by means of mechanical agitation. The followitig section is an explanation of the results and limitations of several correlations relevant to defining MSF performance recjuirements.

\subsection{APPLICATION OF THE ZWIETERING CORRELATION}

Possibly the most popular correlation for suspending insoluble solids in a liquid was one proposed by T. N. Zwietering in 1958. By perforning numerous experuments suspending glass and sand in water, Zweitering oloserved that a relationslip exists between the critical mixing speed required to keep particles in a "just suspended" state and numerous process variables. The just-suspended criterion is defined as no particle resting on the vessel botton for more than 1-2 seconds during agitation has since been a significant characteristic of subsequen1 research. The Zwietering correlation was recommended as a good starting point for evaluating necessary mixing equipment requirements by numerous sources and was, therefore, employed first (Dickey D.S., 2009-5-20; Etchells, et al. 2009; Oldshue 1983; Edwards, et al. 2004)

In its dimensional form, the Zwietering correlation is presented by Etchells at al. (2009) as the following $(\mathrm{Eq}, 3,1)$ :

$$
N_{j S}=s v^{0.1}\left(\frac{g \Delta \rho}{\rho_{l}}\right)^{0.45} X^{0.13} d_{p}^{0.2} D^{-0.85}
$$

where

$$
\begin{array}{lll}
\mathrm{N}_{\mathrm{JS}} & = & \text { just-suspended impeller speed } \\
\mathrm{s} & = & \text { Zwieleritg geonielrical constant } \\
v & = & \text { liquid dynamic viscosity } \\
\Delta \mathrm{p} & = & \text { solids }- \text { liquids density difference } \\
\mathrm{PL} & = & \text { liquids density } \\
\mathrm{X} & = & \text { solids to liquids mass ratio }
\end{array}
$$




$$
\begin{array}{lll}
\mathbf{d}_{\mu} & = & \text { particle diameter } \\
\mathbf{D} & = & \text { impeller diameter } \\
\mathrm{g} & = & \text { acceleration due to gravity }
\end{array}
$$

Once $\mathrm{N}_{\mathrm{SS}}$ is obtained, the power required to tum the impeller can be calculated by Equation $\mathbf{3 . 2}$ (Etchells, et al. 2009).

where

$$
P=P_{0} \rho_{s l u r r y} N^{3} D^{5}
$$

$$
\begin{array}{lll}
\mathrm{P} & = & \text { power } \\
\mathrm{P}_{0} & = & \text { power number } \\
\mathrm{P}_{\text {slumy }} & = & \text { slurry density } \\
\mathrm{N} & = & \text { impeller speed }
\end{array}
$$

As solid particles are dispersed throughout the liquid, the mean density of the mixture will increase. To account for this increase, average slurry density $\left(\rho_{\text {slury }}\right)$ was used to calculate power. Regardless of suspension degree, $\rho_{\text {slury }}$ was calculated as if all particles were dispersed uniformly. Equation 3.3 shows the formula used for $\rho_{\text {slury. }}$

where

$$
\rho_{\text {slurry }}=\frac{100}{\frac{c_{W}}{\rho_{S}}+\frac{100-c_{W}}{\rho_{L}}}
$$

$$
\begin{array}{lll}
c_{w} & = & \text { solids concentration percentage by weight } \\
p_{s} & = & \text { solids density }
\end{array}
$$

Oldshue ( 1983 ) recommends a scale up factor of 1.7 to estimate the impeller speed for uniform suspension $\left(\mathrm{N}_{\mathrm{U}}\right)$ from $\mathrm{N}_{\mathrm{JS}}$ for particle free settling velocities of 16-60 ft/min. This range of free settling velocities was considered because of its conservatism.

$$
N_{U}=1.7 N_{j S}
$$

While it is possible that unifom suspension may not be required for sufficient sampling and transfer, this has not been confimed. Therefore, and on the basis of providing a conservative estimate, this document will consider uniform suspension as the as the necessary suspension requirement for sufficient sampling and transfer.

Regarding scale up, the Zwietering correlation may be applied directly to large-scale applications or a scale up factor may be used. Many scale-up factors have been proposed but literature does little to provide a best reconmendation. As a result, this evalualion opted against a scale up factor and applied the correlation directly. 
Despite its popularity, the Zwietering correlation is not without its limitations. It is not the exclusive solution to all solid-liquid mixing applications. Most notably, perhaps, is that the correlation begins to break down when applied to processes involving variables and parameters not accounted for in its derivation. This particular constraint has proven most cumbersome when attempting to adopt the correlation for use with Hanford tank waste. Several key boundaries limiting its operational range are particle size, particle density, liquid density, and the solid-liquid density difference, $\Delta p$.

The correlation is best suited for suspending two insoluble constituents of uniform properties, such as sand in liquid water. In this case, both the water and sand can be assumed to be of distinct, constant densities, viscosities, etc.... and the standard deviation of each property is relatively small. Actual results may deviate from the correlation when it is applied to substances that have variable physical properties, i.e., variable solids or liquid densities, large variations in particle size, exhibition of non-Newtonian behavior, or use parameters in great excess of the values provided in Table 3-1. After a quick analysis, it became clear that numerous process constituents facing MSF departed significantly from Zwietering's design conditions. Some of these can be observed by comparing Tables 3-1, 3-3 and 3-4.

Table 3-1. Operating conditions over which the Zwietering correlation was obtained (Etchells et al. 2009)

\begin{tabular}{|c|c|}
\hline Parameter & Ranqe covered \\
\hline$\Delta \rho\left(\mathrm{kg} / \mathrm{m}^{3}\right)$ & $560-1800$ \\
\hline$d_{\mu}\left(\mu_{\mathrm{m}}\right)$ & $140-520$ \\
\hline$X(\%)$ & $0.5-20$ \\
\hline$T(\mathrm{~m})$ & $0.1-0.6$ \\
\hline$D / T$ & $1 / 6-1 / 2$ \\
\hline$n_{b}$ & 4 \\
\hline$C / T$ & $1 / 20-1 / 2$ \\
\hline Impel. type & 4 \\
\hline $\begin{array}{c}\text { Vessel base } \\
\text { shape }\end{array}$ & $\begin{array}{c}\text { Flat, dish } \& \\
\text { conical }\end{array}$ \\
\hline$\mu_{L}$ (mPa s) & $0.3-9$ \\
\hline
\end{tabular}

\subsection{COMMENTS ON APPLYING ZWIETERING'S CORRELATION}

Analysis using the Zwietering correlation began by determining average values for each property of interest. The correlation was then applied and analysis made to evaluate suspension requirements facing an "average" batch. However, because tank waste is not conveniently "averaged" over all tanks, further analysis was done by attempting to model several different scenarios. This was intended to provide insight regarding how $\mathrm{N}_{\mathrm{IS}}, \mathrm{N}_{\mathrm{U}}$, and power consumption would respond to more difficult circumstances than presented by an average batch.

RPP-5346 and RPP-9805 provided best-recommendation (BR) estimates for average values based on data collected from eight HLW tanks, which are presented in Table 3-2. While WTP- 
RTP-153 is generally considered the recent source for particle size and density, it is selfadmittedly not conservative. Therefore, in the interest of being conservative. BR solids and liquids properties front RPP-5346 and RPP-9805 were used instead.

Table 3-2. Best-recommendatlon waste property parameters of average HLW

\begin{tabular}{|l|c|}
\hline Property & HLW \\
\hline Particle Size $(\mu \mathrm{m})$ & 7.5 \\
\hline Solids Density $\left(\mathrm{kg} / \mathrm{m}^{\wedge} 3\right)$ & 2900 \\
\hline Liquid Density $\left(\mathrm{kg} / \mathrm{m}^{\wedge} 3\right)$ & 1100,1300 \\
\hline Liquid Viscosity $(\mathrm{cP})$ & $1.5,1.6$ \\
\hline Solids Loading $(\%$ vol) & $\leq 10 \%$ \\
\hline
\end{tabular}

The study summarized in RPP-5346 sought to characterize lank waste plyysical properties in an attempt to define a design basis for pressure drop and transfer pump requirements. Similar to the Zwietering cortelation, pressure drop and related calculations for the transfer systen analysis required representative values for relevant parameters. Rather than attempting to model every different type and concentration of waste that may pass through the transfer lines, one set of parameters was needed that would reliably represent all HLW. The best recommendation properties resulting from this study were developed specifically to meet this need.

Numerons cases were considered in order to develop an understanding of power reguirenents as a function of various waste parameters. To evaluate operational requirements under average waste loadiogs, best recommendation parameters were used (Table 3-2), including the 95:95 tolerance level particle size (RPP-9805). Two best-recommendation values were provided for liquid density, and therefore the average was used ( $1200 \mathrm{~kg} / \mathrm{m}$ ). As another case, and in consideration of larger, denser particles, one solid constituent was evaluated at a tine, the densest of these being $\mathrm{PuO}_{2} . \mathrm{A} \mathrm{10 \%}$ solids concentration (by volume) was assumed and the particle size for each solid constituent was taken to be the naxinum observed by WTP-RPT153. In addition to distinc1 particles, large clusters of agglomerated solids have also been found, the largest of these being $1 \mathrm{~mm}$ in diameter. Therefore, in an attempt to understand performance requirements in the presence of such large particles, additional cases were considered wherein $0.25 \%$ by volume of the solids concentration was assumed to be comprised of particles $1 \mathrm{~mm}$ in diameter. In the case of $\mathrm{PuO}_{2}$, even if all $\mathrm{PuO}_{2}$ present at the Hanford tank farm was transferted in one batch to a 500,000 gallon tatk, its solids concentration would be approximately $0.008316 \%$ by volume, well below $10 \%$. As such, $0.008316 \%$ was used instead of $10 \%$. Further notes on calculations are provided in Appendix $A$.

Because no applicable $s$ values for a hydrofoil impeller operating under the desired process conditions could be procured, a pitched-b]ade turbine with four blades and a $45 \%$ blade angle (PBT4-45) was used. 


\subsection{ZWIETERING RESULTS}

Table 3-3 shows results based on the use of a single PBT $4-45$ and the required impeller speeds and power to aclieve both just-suspension and uniform suspension in a 500,000 gallon vessel. Table 3-4 shows results based on waste parameters identical to those from Table 3-3, but with the employment of two impellers, as is recommended for uniform dispersion in a vessel of $Z T T=$ 1.3 (See Figure B-1 in Appendix B). Tank diameter was taken to be $40 \mathrm{ft}$, and the impeller diameter was taken to be $13.3 \mathrm{ft}$. For both cases power must be increased nearly five times to achieve uniform suspension from just-suspension. Use of two impellers mandates doubling the required power as used with a single impeller.

Calculations contained within this section are preliminary and served to guide the problem of sizing mechanical mixers for mixing Hanford tank HLW sludge toward a more empirical approach to determine proper mixer sizing/configuration. While the preliminary calculations contained herein do not fit the definition of "computation" per TFC-ENG-DESIGN-C-10 (thus requiring no documented calculation check), it was determined that little value would be added by performing a calculation check commensurate with an informal calculation, and therefore none was performed. Users nust recognize this litmitalion and engage in calculation verification as per TFC-ENG-DESIGN-C-10 if tesults from calculations are used explicitly. 
Table 3-3. Zwietering correlation results for 1 PBT4-45 impeller

\begin{tabular}{|c|c|c|c|c|c|c|c|c|c|c|}
\hline Conditions $\left(\rho_{s} / \rho_{\mathrm{J}} / \mathrm{d}_{\rho}\right)$ & $\mu_{L}\left(\mathrm{Ns}_{\mathrm{s}} / \mathrm{m}^{\wedge} \mathrm{z}\right.$ & $\rho s\left(\mathrm{~kg} / \mathrm{m}^{\wedge} \mathrm{3}\right)$ & $\rho_{\mathrm{L}}\left(\mathrm{kg} / \mathrm{m}^{\wedge} \mathrm{3}\right)$ & $\rho_{\text {slurry }}\left(\mathrm{kg} / \mathrm{m}^{\wedge} 3\right)$ & solid vol \% & $d_{p}(\mu \mathrm{m})$ & $\mathrm{N}_{\mathrm{JS}}$ (rpm) & $\mathrm{N}_{\mathrm{JS}}$ Power $(\mathrm{HP})$ & $\mathrm{N}_{\mathrm{U}}(\mathrm{pm})$ & $\mathrm{N}_{\mathrm{U}}$ Power (HP) \\
\hline BR/BR Mean/BR & $1.60 \mathrm{E}-03$ & 2900 & 1200 & 1370 & 10 & 7.5 & 15.5 & 44.4 & 26.3 & 218.3 \\
\hline BR/BR Mean/95-95 TL & 1.60E-03 & 2900 & 1200 & 1370 & 10 & 22 & 19.2 & 84.7 & 32.6 & 416.4 \\
\hline BR/BR Mean/Zwietering Min & $1.60 \mathrm{E}-03$ & 2900 & 1200 & 1370 & 10 & 140 & 27.8 & 257.3 & 47.3 & 1264.0 \\
\hline $\mathrm{PuO}_{2} / \mathrm{BR}$ Mean/Max Observed & $1.60 \mathrm{E}-03$ & 11430 & 1200 & 1201 & 0.008316 & 40 & 22.7 & 123.5 & 38.7 & 607.1 \\
\hline $\mathrm{PuO}_{2} / \mathrm{BR}$ Mean/Max Agglom. & $1.60 \mathrm{E}-03$ & 11430 & 1200 & 1200 & 0.0004158 & 1000 & 29.3 & 265 & 49.9 & 1302 \\
\hline $\mathrm{Bi}_{2} \mathrm{O}_{3} / \mathrm{BR}$ Mean/Max Observed & $1.60 \mathrm{E}-03$ & 8900 & 1200 & 1970 & 10 & 10 & 37.4 & 903.8 & 63.7 & 4440 \\
\hline $\mathrm{Bi}_{2} \mathrm{O}_{3} / \mathrm{BR}$ Mean/Max Agglom. & $1.60 \mathrm{E}-03$ & 8900 & 1200 & 1219 & 0.25 & 1000 & 57.5 & 2020 & 97.7 & 9925 \\
\hline $\mathrm{ZrO}_{2} / \mathrm{BR}$ Mean/Max Observed & $1.60 \mathrm{E}-03$ & 5680 & 1200 & 1648 & 10 & 50 & 38.2 & 802.3 & 65.0 & 3941 \\
\hline $\mathrm{ZrO}_{2} / \mathrm{BR}$ Mean/Max Agglom. & 1.60E-03 & 5680 & 1200 & 1211 & 0.25 & 1000 & 42.5 & 810.8 & 72.2 & 3983 \\
\hline
\end{tabular}

Table 3-4. Zwietering correlation results for 2 PBT4-45 impellers

\begin{tabular}{|c|c|c|c|c|c|c|c|c|c|c|}
\hline Conditions $\left(\rho_{s} / \rho_{1} / d_{\rho}\right)$ & $\mu_{L}\left(\mathrm{Ns} / \mathrm{m}^{\prime} 2\right)$ & $\rho_{s}\left(\mathrm{~kg} / \mathrm{m}^{\wedge} 3\right)$ & $\rho_{\mathrm{L}}\left(\mathrm{kg} / \mathrm{m}^{\mathrm{n}} \mathrm{3}\right)$ & $\rho_{\text {slurry }}\left(\mathrm{kg} / \mathrm{m}^{\wedge} \mathrm{3}\right)$ & solid vol \% & $d_{p}(\mu m)$ & $\mathbf{N}_{\mathrm{j5}}$ (rpm) & $\mathrm{N}_{1 \mathrm{~s}}$ Power (HP) & $N_{u}$ (rpm) & $N_{u}$ Power (HP) \\
\hline BR/BR Mean/BR & $1.60 \mathrm{E}-03$ & 2900 & 1200 & 1370 & 10 & 7.5 & 15.5 & 88.8 & 26.3 & 436.6 \\
\hline BR/BR Mean/95-95 TL & $1.60 \mathrm{E}-03$ & 2900 & 1200 & 1370 & 10 & 22 & 19.2 & 169.4 & 32.6 & 832.8 \\
\hline BR/BR Mean/Zwietering Min & $1.60 \mathrm{E}-03$ & 2900 & 1200 & 1370 & 10 & 140 & 27.8 & 514.6 & 47.3 & 2528.0 \\
\hline $\mathrm{PuO} / \mathrm{BR}$ Mean/Max Observed & $1.60 \mathrm{E}-03$ & 11430 & 1200 & 1201 & 0.008316 & 40 & 22.7 & 247.0 & 38.7 & 1214.2 \\
\hline $\mathrm{PuO}_{2}$ /BR Mean/Max Agglom. & $1.60 \mathrm{E}-03$ & 11430 & 1200 & 1200 & 0.0004158 & 1000 & 29.3 & 530.0 & 49.9 & 2604.0 \\
\hline $\mathrm{Bi}_{2} \mathrm{O}_{3} / \mathrm{BR}$ Mean/Max Observed & $1.60 \mathrm{E}-03$ & 8900 & 1200 & 1970 & 10 & 10 & 37.4 & 1807.6 & 63.7 & 8880.0 \\
\hline $\mathrm{Bi}_{2} \mathrm{O}_{3} / \mathrm{BR}$ Mean/Max Agglom. & 1.60E-03 & 8900 & 1200 & 1219 & 0.25 & 1000 & 57.5 & 4040.0 & 97.7 & 19850.0 \\
\hline $\mathrm{ZrO} / \mathrm{BR}$ Mean/Max Observed & 1.60E-03 & 5680 & 1200 & 1648 & 10 & 50 & 38.2 & 1604.6 & 65.0 & 7882.0 \\
\hline ZrO2/BR Mean/Max Agglom. & 1.60E-03 & 5680 & 1200 & 1211 & 0.25 & 1000 & 42.5 & 1621.6 & 72.2 & 7966.0 \\
\hline
\end{tabular}


RPP-RPT-42527, Rev, 0

\subsection{ZWIETERING CORRELATION CONCLUSION}

While the Zwietering correlation is not well suited for application in this particular study due to its narrow range of acceptable parameters, it did result in at least one useful observation. It is clear that a very sizeable increase in power is necessary to achieve uniform suspension from justsuspension.

\section{ANALYTICAL TECHNIQUES - THE OLDSHUE TECHNIQUE}

Application of the Zwietering correlation is very limited in many regards and insufficient for developing a set of functional requirements for MSF. Therefore, pursuit of a more reliable and comprehensive techniques ensued. Several techniques were applied or considered and their results conpared. The first of these techniques originates from Fluid Mixing Technology, by James Oldshue, and for lack of a better term, will be referred to as the Oldshue technique.

\subsection{THE OLDSHUE TECHNIQUE}

The Oldshue technicue was developed as a rough guide for estimating power requirements for relatively small scale plant application stimed vessels. It involves using a series of visual graphical interpretations, rather than equations, to determine mixing equipment requirements.

One distinct benefit of the Oldshue technique over Zwietering's correlation is that it is inherently inclusive of conditions for uniform suspension. Unfortunately, however, it is not without limitations. Most notably, direct application of this method is limited to mixing vessels ranging from 1,000 to 30,000 gallons in volume. This restriction resulted in the need for some form of a scale up procedure (See Appendix A for details regarding scale up method). Oldshone notes that while the technique provides a fairly conservative power requirement estimate, laboratory scale testing may be recjuired to fine-tune some slurry variables (Oldshue, 1983).

\subsection{APPLYING THE OLDSHUE TECHNIQUE}

Unlike the Zwietering correlation, which yields an impeller speed, the Oldshue technique yields an estimated power requirement for both $\mathrm{N}_{\mathrm{s}}$ and $\mathrm{N}_{\mathrm{V}}$. Using the power requirement for uniform suspension, Equation 3.2 can be rewritten in the following form to produce an impeller speed:

$$
N_{U}=\left[\frac{P}{P_{O \rho_{S l}+\gamma_{j} D^{5}}}\right]^{1 / 3}
$$

When two impellers are used the power number may increase by a factor of two, such that $P_{O}=$ $2 \mathrm{P}_{0}$. 
The Oldshue technique requires settling velocity as a functional parameter, rather than density and particle size, like the Zwietering correlation. Settling velocity $\left(V_{S}\right)$ was calculated by the following equation:

$$
V_{s}=1.73\left[\frac{d_{p} g\left(\rho_{s}-\rho_{L}\right)}{\rho_{L}}\right]^{1 / 2}
$$

Equation 4.2 represents a particle's free settling velocity in the turbulent regime as provided by Edwards, et al. (2004). Since mixing and particle dispersion by means of mechanical agitation take place in the presence of turbulent flow patterns, turbulent conditions were assumed and use of this expression is reasonable.

Table 4-1 shows a list of cases which the Oldshue technique was applied to. Scenario 1 represents equipment requirements based on a settling velocity corresponding to bestrecommendation values for particle size and solids density, and best-recommendation average for liquid density. Scenario 2 incorporates the $95 / 95$ tolerance limit particle size offered in RPP9805. This is the value for which the authors of said document feel $95 \%$ confident that $95 \%$ of tank waste particles will be lower than. Scenarios 3 and 4 represent conditions of intermediate settling velocities. Scenario 5 uses Zwietering minimum recommended operational values. Scenario 6, while not included in further calculations, shows the free settling velocity of a $\mathrm{PuO}_{2}$ agglomerate, the largest, most dense particle assumed to be in sludge waste. Because the Oldshue technique is only able to account for settling velocities up to $20 \mathrm{ft} / \mathrm{min}$, it was included merely for the purpose of comparison to other settling velocities.

Table 4-1. Particle free-settling velocities

\begin{tabular}{|c|c|c|c|c|c|}
\hline Scenario & Metric & $d_{p}(\mu \mathrm{m})$ & $\rho_{s}(\mathrm{~kg} / \mathrm{m} \cap 3)$ & $\rho_{L}\left(\mathrm{~kg} / \mathrm{m}^{n} 3\right]$ & $V_{s}(t t / m i n)$ \\
\hline & $\begin{array}{l}\text { Best recommended values } \\
\text { (RPP-9805) }\end{array}$ & 7.5 & 2900 & 1200 & 3.47 \\
\hline & 95/95 TL (RPP-9805) & 22 & 2900 & 1200 & 5.95 \\
\hline & Intermediate Value & - & - & $\cdot$ & 5 \\
\hline & Intermediate Value & - & - & - & 8 \\
\hline & $\begin{array}{l}\text { Zwietering Minimum } \\
\text { Operating Values }\end{array}$ & 140 & 2900 & 1200 & 15.02 \\
\hline & $\begin{array}{l}\text { Heaviest, Most Dense Particle } \\
\left(\mathrm{PuO}_{2} \text { Agglomerate) }\right.\end{array}$ & 1000 & 11430 & 1200 & 98.49 \\
\hline
\end{tabular}

Table 4-2 shows the results obtained when the Oldshue correlation was applied to the cases listed in Table 4.1 (excepting Scenario 6). These calculations assumed the following parameters:

- Two impellers, PBT4-45 style with $\mathrm{W} / \mathrm{D}=0.2$ and $\mathrm{P}_{\mathrm{O}}=1.27$

- Standard 4-baffle configuration; baffles of width T/10 to T/12 
- $\mathrm{Z} / \mathrm{T}=1.3 ; \mathrm{D} / \mathrm{T}=1 / 3$

- $10 \%$ by volume solids concentration

- Vessel volume of 500,000 gallons

Table 42. Power and impeller speed predictions

\begin{tabular}{|c|c|c|}
\hline Settling Velocity $(\mathrm{ft} / \mathrm{min})$ & $\mathrm{N}_{\mathrm{U}}(\mathrm{rpm})$ & Power $(\mathrm{HP})$ \\
\hline $\mathbf{3 . 5}$ & 20.8 & 200.4 \\
$\mathbf{5}$ & 27.1 & 442.6 \\
$\mathbf{6}$ & 31.6 & 700 \\
$\mathbf{8}$ & 36.7 & 1195 \\
$\mathbf{1 4}$ & 44.2 & 1919 \\
\hline
\end{tabular}

Further analysis was done utilizing the Oldshue technique's flexibility to represent the optimal impeller geometry. The Oldshue technique accounts only for a PBT4-45 style impeller, rather than the recommended hydrofoil style (Tatterson 2009-5-21). The method used to adapt the Oldshue technique to an alternative impeller style consisted of modifying the power number. Results are compared in Table 4-3 below. Further notes on calculations are provided in Appendix A.

Table 4-3. Power consumption based on Oldshue Technique

\begin{tabular}{|c|c|c|c|}
\hline Settling Velocity (tt/min) & $\mathbf{N}_{\mathrm{U}}(\mathrm{rpm})$ & $\begin{array}{c}\text { PBT4-45 } \\
\text { Power (HP) }\end{array}$ & $\begin{array}{c}\text { A-2 Hydrofoil } \\
\text { Power (HP) }\end{array}$ \\
\hline $\mathbf{3 . 5}$ & 20.8 & 200.4 & 94.7 \\
$\mathbf{5}$ & 27.1 & 442.6 & 209.1 \\
$\mathbf{6}$ & 31.6 & 700 & 330.7 \\
$\mathbf{8}$ & 36.7 & 1195 & 564.5 \\
$\mathbf{1 5}$ & 44.2 & 1919 & 906.5 \\
\hline
\end{tabular}

\subsection{OLDSHUE TECHNIQUE CONCLUSION}

The attempt to apply the Oldshue technique as a better means of estimating agitator speed and power requirements was met with mixed success. Because its application involves numerous graphical interpretations rather than discrete equations, results may vary. Furthermore, it is not known how well the technique applies when adapted for scale up or alternate impeller styles. In its defense, the Oldshue technique was able to accommodate a much wider range of process variables than that of the Zwietering correlation.

When presented with the best recommendation average particle size and densities, application of the Oldshue technique estimated a necessary power requirement of $200.4 \mathrm{HP}$ operating at 29.0 rpm with two PBT4-45 impellers. When A-2 style hydrofoils are substituted for the PBT 
impellers and operated at the sane sped, the power consumption is reduced by more than lalf: to $94.7 \mathrm{HP}$.

Calculations contained witlin this section are preliminary and served to guide the problem of sizing mechanical mixers for mixing Hanford tank HLW sludge toward a more empirical approach to detemine proper mixer sizingiconfiguration. While the prelininary caleulatious contained herein do not fi1 the definition of "computation" per TFC-ENG-DESIGN-C-10 (thus requiring no documented calculation check), it was determined that little value would be added by performing a calculation check conmensurate with an informal calculation, and therefore none was performed. Users must recognize this limitation and engage in calculation verification as per TFC-ENG-DESIGN-C-10 if results from calculations are used esplicitly.

\section{ANALYTICAL TECHNIQUES - MODIFIED FROUDE NUMBER CORRELATION}

The third cortelative approach considered for estimating the power and speed requirements for a mechanically agitated system was provided by Dr. Gary Tatterson, a professor of chemical engineering at the University of Arkansas. Dr. Tatterson, a recognized expert in tluid mixing, recommended a correlation based on a modified Froude number developed by C. Bumman (Buminan et a1.. 1986).

Limitations of the MFN correlation were very similar to those experienced by the Zwietering correlation. The parameters over which the correlation was obtained are too narrow to acconmodate actual tank waste process parameters. For this reason, application of the MFN correlation was not pursued.

\section{CONCLUSION ON CORRELATIVE TECHNIQUES}

In short, use of the Zwietering and modified Fronde number correlations is not recommended due to their severe deviations from the recomnended operational range. Figure $6-1$ is provided as a comparison of several design parameter ranges to the corresponding recommended range for each correlation. Of the three correlative technicues evaluated. the Oldshut technique proved most promising, as it incorporated the larges1 operational range. Of the three techniques evaluated. it may be the best method for quickly estimating MSF power and speed requirements. However, the Oldshue technique accounts only for use of a 4 blade $45^{\circ}$ pitch blade turbine impeller, and numerous assumptions must be made to adapt it for use with alternate impeller styles. It should also be noted that only testing can confirm the reliability of any of these correlations and until such testing is performed one should exercise caution when applying them. Application of the Oldshue technique and related assumptions (as discussed in Section 4) yielded 
a required impeller power of $95 \mathrm{HP}$ at $29 \mathrm{rpm}$ to suspend waste with a $3.5 \mathrm{ft} / \mathrm{min}$ average settling velocity.

\section{Figure 6-1. Parameter range comparison}

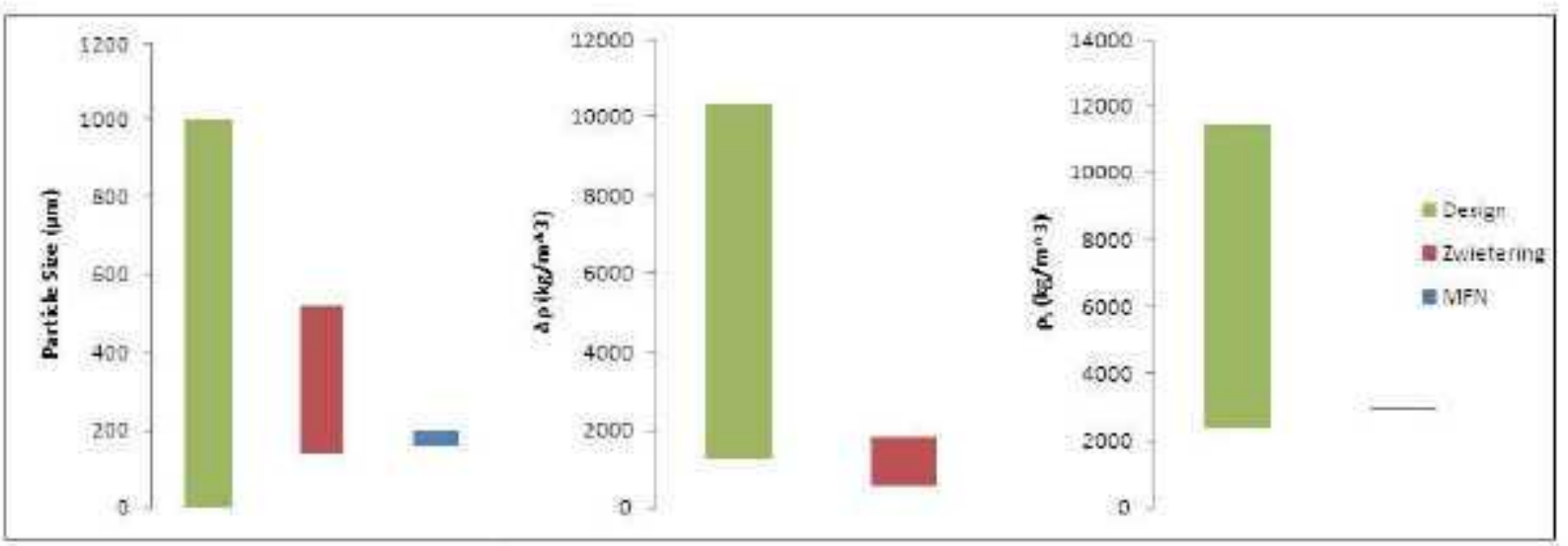

\section{ALTERNATIVE METHODS}

\subsection{COMPUTATIONAL FLUID DYNAMICS}

Computational fluid dynamics (CFD) is an analytical method that has risen in popularity as computer technology has advanced. It is a simulation method for studying fluid flow patterns that involves numerous iterations of mathematic computations. Due to its mathematically intense nature, it is carried out almost exclusively using computers. While it is widely used for many fluid flow applications, its adoption for use in the mixing industry has not gone unchallenged.

Numerous industry experts claim that CFD alone is currently insufficient for determining and guaranteeing hardware requirements to meet specific desired process results. While they acknowledge that CFD is very usefill for understanding such things as fluid flow pattems and velocity fields, it may not sufficiently model solids suspension (Meyer, et al.2009). When applied in conjunction with scaled model testing, however, CFD may provide useful data and greater confidence regarding scale-up procedures.

Because CFD modeling is expensive and resources to perform the evaluation were not readily available, its implementation was not considered within the scope of this repont.

\subsection{SCALED MODEL TESTING}

If there is one universal theme that propagates itself among mixing professionals it is that there is no substitute for scaled testing. All conrelations found in literature originated from scaled testing. Quite often, their experimental procedure and process variables are intended to represent an "average" application. In the common event that a particular process cannot be described by 
these correlations, scaled testing is the only failsafe means of solution. Correlations can then be made that apply specifically to one"s unique process.

Scale model testing involves the development of vessels intended to represent the behavior of another, often larger, vessel. Tests are conducted with these vessels which would be too difficult, time consuming, or expensive to do at full-scale. Most tests are designed around developing correlations for vessel scale up. When done correctly, scaled model testing is the most reliable teclnique for determining mixing system requirements.

Many considerations must be made when attempting a scaled test program. Aspects such as simulant selection and geometric similitude play significant roles in delemining the accuracy of test results and how applicable they are to the intended application. Incorrect scaling procedures will result in erroneous data. Implementation of a scaled model test program is discussed further in Section 8 .

\subsection{EXPERT APPEAL - PHILADELPHIA MIXING SOLUTIONS, LTD.}

When it became apparent that cortelations and text-book methods were likely to be insufficient for developing functional requirements for the MSF mixing system, contast was nade with Philadelphia Mixing Solutions, Ldd. (PMSL). PMSL is the NQA-1 certified supplier of mechanical mixing ecjujpment for Bechtel, the WTP contractor, and their equipment has been installed extensively and employed successfully in the nuclear industry for nany years. Based on the PSDD from Table 7-1, they generated an estimation of the power and speed requirements for uniform and homogeneous suspension. 
Table 7-1. PSDD as utilized by PMSL

\begin{tabular}{|c|c|c|c|}
\hline Solid-Phase Compound & $\begin{array}{l}\text { Crystal } \\
\text { Density } \\
(\mathrm{g} m \mathrm{~m})\end{array}$ & $\begin{array}{l}\text { Volume } \\
\text { Fraction }\end{array}$ & $\begin{array}{c}\text { Masimum } \\
\text { Observed } \\
\text { Particle Size } \\
\text { ( } \mu \mathrm{m})\end{array}$ \\
\hline $\mathrm{Al}(\mathrm{OH})_{4}$. Gibbsite & 242 & 0515 & 20 \\
\hline$\left(\mathrm{NaA}_{2} \mathrm{StO}_{4}\right)_{0} \cdot\left(\mathrm{Na} \mathrm{NO}_{3}\right)_{2} \cdot 0^{*} 2 \mathrm{H}_{2} \mathrm{O}$ & 2.365 & 0.166 & 8 \\
\hline AlOOH, Bochminte & 301 & 0.106 & 0.05 \\
\hline $\mathrm{NaAlCO}_{3}(\mathrm{OH})_{2}$ & 242 & 0.095 & 42 \\
\hline $\mathrm{Fe}_{2} \mathrm{O}_{3}$ & 5.24 & 0041 & 1.6 \\
\hline $\mathrm{Ca}, \mathrm{OH}\left(\mathrm{PO}_{4}\right)_{3}$ & 3.14 & 0020 & 0.1 \\
\hline $\mathrm{Na}_{2} \mathrm{U}_{2} \mathrm{O}_{7}$ & 5.017 & 0.016 & 15 \\
\hline $\mathrm{ZrO}_{2}$ & 5.68 & 0.011 & 50 \\
\hline $\mathrm{B}_{12} \mathrm{O}_{3}$ & 89 & 0.0081 & 10 \\
\hline $\mathrm{SiO}_{2}$ & 26 & 0.0069 & 100 \\
\hline $\mathrm{Ni}(\mathrm{OH})_{2}$ & 41 & 0.0055 & 0.5 \\
\hline $\mathrm{MnO}_{2}$ & 5.026 & 0.0054 & 10 \\
\hline $\mathrm{CaF}_{2}$ & 3.18 & 0.0023 & 15 \\
\hline $\mathrm{LaPO}_{+} \cdot 2 \mathrm{H}=\mathrm{O}$ & 6.51 & 00013 & 3 \\
\hline $\mathrm{Ag}_{2} \mathrm{CO}_{3}$ & 6.077 & 0.000094 & 4 \\
\hline $\mathrm{PuO}_{2}$ & 11.43 & 0000013 & 40 \\
\hline
\end{tabular}

In order to calculate mixer design requirements, PMSL requested an estimated PSDD representative of sludge waste. Table 7-1 was a PSDD developed in WTP-RPT-153 and was provided to meet this request. The best recommendation particle size resulting from the WTPRPT-153 study was $7.7 \mu \mathrm{m}$, and PMSL calculated a solids density of $2774 \mathrm{~kg} / \mathrm{m}^{3}$ based on the PSDD given in Table 7-1. Liquids density was given as $1200 \mathrm{~kg} / \mathrm{m}^{3}$ and solids concentration as $10 \%$ by volume.

Table 7-2 lists suspension speed and power requirements for an average particle settling velocity of $0.6577 \mathrm{ft} / \mathrm{min}$ (as calculated by PMSL). In this case, homogeneous (as opposed to uniform) is the desired degree of suspension. For homogeneous suspension based on the provided PSDD, PM recommends a $114 \mathrm{HP}$ motor operating a $23 \mathrm{rpm}$.

Table 7-2. PMSL's recommended speed and power requirements

\begin{tabular}{|c|c|c|c|c|c|c|c|c|c|c|}
\hline $\begin{array}{l}\text { Solics } \\
\text { Susperiam }\end{array}$ & $\begin{array}{c}\text { lwat } \\
\text { Sespendex }\end{array}$ & * & Otf Bettom & - & $\begin{array}{l}\text { Prsterate } \\
\text { Unifominty }\end{array}$ & - & $\begin{array}{l}\text { Nearly } \\
\text { Uniform }\end{array}$ & $=$ & Uniform & - \\
\hline Leyel & Jue Suapended & 2056 u nifarmitr & $35 \times$ Un itamity & sos Uniformity & Eox Unifarmity & rovunifom nr & sos Unife mity & 908 Lnitannity & Untorm Sura & Homosenecus \\
\hline Mxer RPM & 10 & 11 & 13 & 14 & 15 & 16 & 17 & 19 & 20 & 23 \\
\hline Power ( $\mathrm{HP}$ ) & 9.38 & 1248 & 20,01 & 2574 & 91.65 & 38.42 & $\triangle 6.08$ & 64.33 & 7503 & 214.11 \\
\hline Tarcue flb int & 5911224 & 71524.86 & 9989635 & 115855.24 & 13209621 & 151219.27 & 17022442 & 21338097 & 23643238 & 312679 \\
\hline
\end{tabular}

These values were generated by PMSL's own proprietary process. PMSL has developed a computer program that catalogs and analyzes data from past tests. These results become part of their comprehensive computer model for determining mixer specifications. This method, which is essentially based on a torqueunit volume approach, has been implemented successfully in the design of more than 40,000 mixers. The largest mixer designed by PMSL is six million gallons 
in volume. Design by this procedure has been confirmed by subsequent lab testing and field testing and has resulted in no waranty clains made by custoners regarding solids suspension performatice (Hutchioson, T., 2009-8-7).

Despite confidence in the recommendations produced by the PMSL model, a PMSL company representative agreed that scaled testing is the only troc means by which to confirm mixer performance, and reconumended such an approach for the MSF application. Appendix B shows the complete spreadsheet and preliminary design sketch for recommended vessel geometry as generated by PMSL.

\section{CONCLUSION AND RECOMMENDATIONS}

The primary goal of this assignment was a success to the extent that it evaluated the validity of employing a correlation, such as that of Zwietering, to the MSF mixing design strategy. In short, correlations and teclinicjues found in publicly accessible literature are largely insufficient due to the complexity of Hanford tank waste. They are developed to handle a tight range of process variables and Hanford tank waste and other application parameters fall well outside these parameters in most cases. The one exception was that of the Oldshue technique. Application. linitations, and results from this method are presented in a Section 4.1. Pending the determination of a reliable particle settling velocity (of less than $20 \mathrm{ft} / \mathrm{min}$ ), approximate power and speed estimates may be made without exceeding the technique's recommended operational range. However, scale up is required for this technique and the scale up method and adaptation for different impeller styles employed in this investigation have not been experimentally verified. When compared to the results provided by Philadelphia Mixing Solutions, the Oldshue teclunique estimated a required power within $17 \%$ of the PMSL recommendation. Oldshue estimates a required impeller power of $94.7 \mathrm{HP}$ at $29 \mathrm{rpm}$ for a settling velocity of $3.5 \mathrm{ftmin}$. PMSL recommends $114 \mathrm{HP}$ at $23 \mathrm{RPM}$ for a much lower settling velocity of 0.6577 . The observer must note that while the power and speed estimations provided by both sources are similar, the settling velocities used to calculate them are not. Regardless of the fact that the Oldshue correlation can be applied within its recommended operational range, it is in need of confimation by physical testing before any definitive decision can be made conceming its validity.

Because no correlations were found that provided confirmed. reliable results, alternative methods were pursted. Of those considered, none proved more dependable than an appeal to industry experts at Philadelphia Mixing Solutions. Based on calculations using valtes provided in Table 7.1. PMSL was able to provide fairly confident reconmendations for tequired agitator speed and power consumption for varying degrees of suspension. For homogenous suspension these recommendations were approximately $114 \mathrm{HP}$ a1 $23 \mathrm{cpm}$.

While confident in their recommendations, PMSL agreed that scaled testing was the only failsafe way to ensure the desired mixing requirements are met. This statement coneurs with similar 
statements made by nunterous other sources that suggest complex mixing challenges should not rely on correlations, but rather data collected from scaled tests designed for its specific application (ChemicalProcessing.cont, Oldshue 1983). Therefore, the final recommendation based on research done within the scope of this report is to team with experienced mixing professionals and develop a scaled testing and developntent program. The consultant( $(s)$ must have notable experience developing mixing systems that process broad particle size and density distributions in large vessels, ideally in the nuclear industry. Such a program would eliminate nuch risk and provide a level of confidence unattainable with any generic correlation. 


\section{REFERENCES}

24590-WTP-ICD-MG-01-019, 2007. ICD-19-Interface Control Document for Waste Feed Rev, 4, Becthel National, Inc., Richland, Washinglon.

Bunrman, C,; Resoort, G.; Plaschkes, A. (1986). Scaling-Up Rules for Solids Suspension in Stirred Vessels.Chemcal Engmeerng Scrence, 41, 2865-287 I

ChemicalProcessing.com, 2009-5-20, [Dickey, D.S., Are there Imtations to the Zweterng correlation for stispending soltds in hquds?]. http: $/$ www,chenicalprocessing,com/expertsianswers $/ 2009 / 069 . \mathrm{html}$

Dickey, D.S., 2009-5-20. :"RE: Zwietering." (e-mail to P.W. Griffin), Washington River Protection Solutions, Richland. Washinglon

Edward, Paul L.; Atiemo-Obeng, Victor A..; Kresta, Suzanne M. (2004). Handbook of Industral Mixing-Sorence and Practice. Joln Wiley \& Sons

Etchells, A., Alderman, N., Heywood, N., 2009 "Solids Liquid Mixing," in Sirry Handhng and Mixing in the Nuclear Industry, Kennewick. Washington

Hutchinson, T, 2009-8-7, :"RE: Thank you," (e-mail to P. W. Griffin), Washington River Protection Solutions, Richland, Washington

Oldshue, James Y. (1983) Flud Mrang Technology: New York: Chemical Engineering McGraw-Hill Pub. Co.

Meyer, P., Bamberger, J., Wells, B., Ganglitz, P., Fort, J., 2009 "CFD," in Jet M/tring Expenence at PNNL, Richland, Washington

RPP-5346, 2002, Waste Feed Delnery Transfer System Anclyss

Rev. 2. CH2MHill Hanford Group, Inc., Richland, Washington

RPP-9805, 2002, Vatues of Particle Size, Farticte Density, and Shrry Viscosity to Uise in Waste Feed Detnery Transfer System Analysis, Rev, 1, Office of River Protection, Richland. Washinglon

Tatterson, G.B., 2009-5-21, :"Solids Suspension," (e-mail to P.W. Griffin), Washington River Protection Solutions, Richland. Washinglon 
RPP-RPT-42527, Rev, 0

Tatterson, G.B, 2009-5-26, :'RE: Solids Suspension," (e-mail to P.W. Griffin), Washington River Protection Solutions, Richland, Washington

TFC-ENG-DESIGN-C-10, "Engineering Calculations," Waslington River Protection Solutions LLC, Richland, Washington

WTP-RPT-153, Esthmate of Hanford Waste Insoluble Solld Particle Size and Densty: Dtstributon Rev. 0, Battelle-Pacific Northwest Division, Ricltand. Washington 
RPP-RPT-42527, Rev, 0

APPENDIX A

NOTES ON CALCULATIONS 


\section{A.1 ZWIETERING CORRELATION}

Regarding the Zwietering correlation, values for $s$ are dependent on impeller configuration and orientation, including blade pitch, number of blades, $\mathrm{C} / \mathrm{T}$, and $\mathrm{T} / \mathrm{D}$, where $\mathrm{C}, \mathrm{T}$, and $\mathrm{D}$ are impeller clearance from vessel bottom, vessel diameter, and impeller diameter, respectively. As the goal of these calculations was primarily to reflect change in shaft speed and power demands as related to likely variations in waste properties, $s$ was held constant at 6.95 (Etchells, et al. 2009). This value corresponds to a PBT4-45 impeller with $\mathrm{C} / \mathrm{T}=1 / 3$ and $\mathrm{T} / \mathrm{D}=3$.

Equation A.1-1 shows the solids to liquids mass ratio as applied in the calculations in Section 3.

$$
X=\frac{\rho_{s} v_{s}}{\rho_{L}\left(1-v_{s}\right)}
$$

It should be noted that in many instances, the actual $X$ value used in calculations presented in Tables 3-3 and 3-4 exceeded the recommended operational range of $2-15 \%$.

The power number, $\mathrm{P}_{\mathrm{O}}$, is a dimensionless drag factor, analogous to the friction factor in pipe flow. It is affected primarily by impeller geometry and flow regime. Oldshue (1983) provides numerous values for $\mathrm{P}_{O}$ for differing impeller types. $\mathrm{P}_{O}$ as used in the calculations made in Section 3 of this document is 1.27, the power number for a 4-blade, pitched blade turbine (PBT) with a blade angle of 45 degrees operating in turbulent conditions (Oldshue 1983). When properly spaced, the power approaches proportionality to the number of impellers. Therefore, if two impellers are utilized, the power required to turn them would be double that of one impeller operating at the same speed (Tatterson 2009-5-26).

\section{A.2 OLDSHUE TECHNIQUE}

As mentioned previously, the Oldshue technique may only be directly applied to vessels 1,000 to 30,000 gallons in volume. The scale up procedure used to estimate values at full scale consisted of applying the Oldshue technique to a series of small scale vessels (between 1,000 and 30,000 gallons). The $\mathrm{N}_{\mathrm{u}}$ power to vessel volume ratio was then plotted against vessel diameter and a best-fit line was generated which allowed for an estimation of required power at full scale, for a given particle settling velocity. Figure A-1 shows the plot used for scale-up. 
Figure A-1. Oldshue scale-up plot

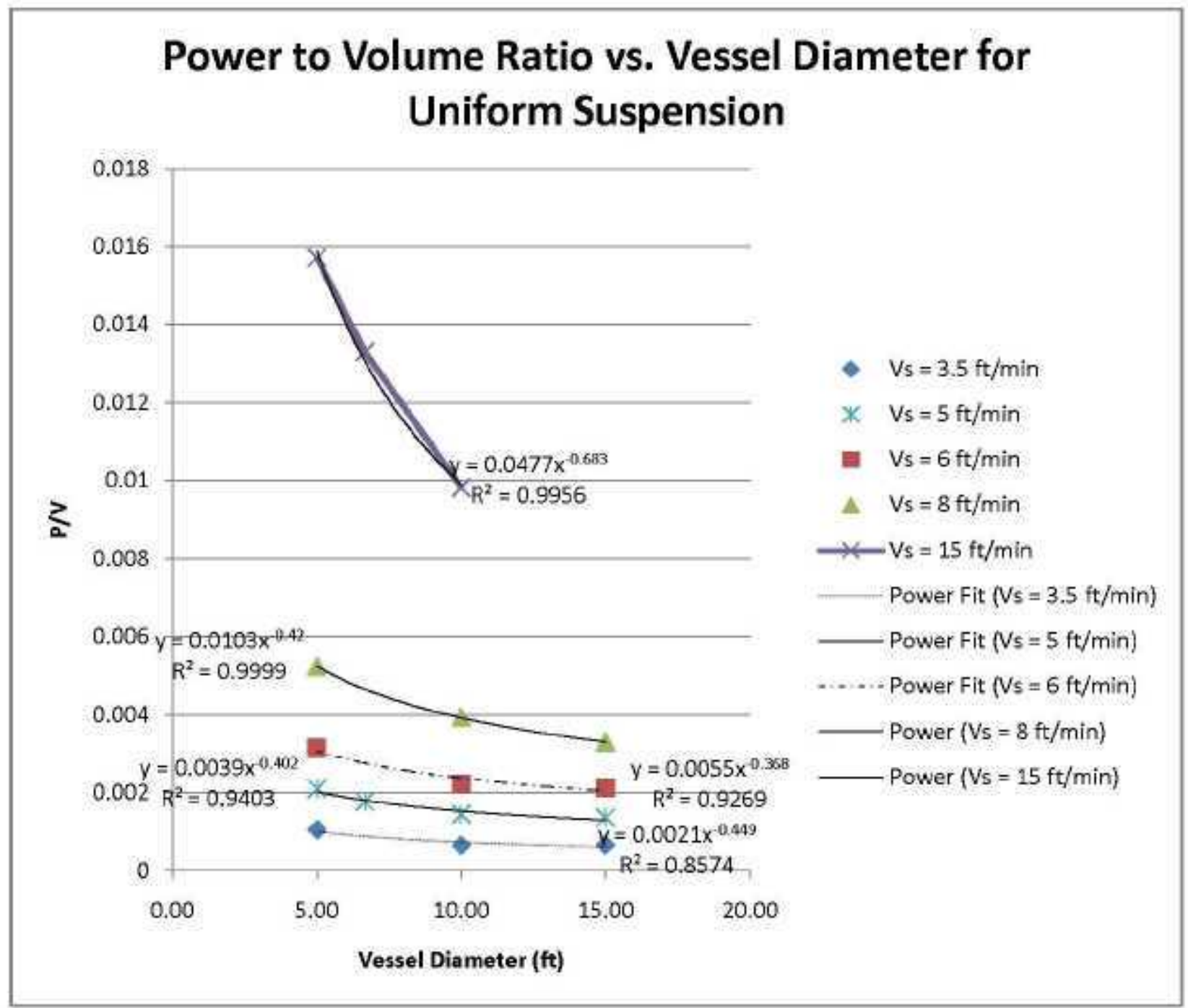

Further analysis was done utilizing the Oldshue technique's flexibility to represent the optimal impeller geometry. The Oldshue technique accounts only for a PBT4-45 style impeller, rather than the recommended hydrofoil style (Tatterson 2009-5-21). The method used to adapt the Oldshue technique to an alternative impeller style consisted of modifying the power number. $\mathrm{P}_{0}$ for a standard 4-blade hydrofoil is 0.6 (Tatterson, 2009-5-26). Taking the ratio of $\mathrm{P}_{\mathrm{O}, \mathrm{H}} / \mathrm{P}_{\mathrm{O}, \mathrm{PBT}}=$ 0.472 . This ratio is expected to represent the power consumption of a hydrofoil to that of a PBT. By multiplying the estimated PBT power consumptions from Table 4.4 by this ratio, an estimate of power consumption with a hydrofoil operating at the same speed may be made. 
RPP-RPT-42527, Rev, 0

APPENDIX B

INFORMATION FROM PHILADELPHIA MIXING SOLUTIONS, LTD. 


\section{Figure B-1. PMSL suspension spreadsheet}

SOLIDS SLSPENSIOV CALCULATION

Gluck here for defimition:

\begin{tabular}{|c|c|}
\hline Duscription & Dota Ent \\
\hline Impeler Type: & LS39 (Axal Flow) \\
\hline Number af inpoles: & 2 \\
\hline Vesselzt & 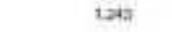 \\
\hline Veasel Dismaier [in] & no \\
\hline mpoter DIT & on \\
\hline Solids Sotting flate ftim] & antos \\
\hline Lurry Denslity is a? & $1 \mathrm{u}$ \\
\hline Slurry veoos ty [of] & If \\
\hline \multirow[t]{2}{*}{ Eacat voume $[q 21]$} & conset \\
\hline & Conita \\
\hline
\end{tabular}

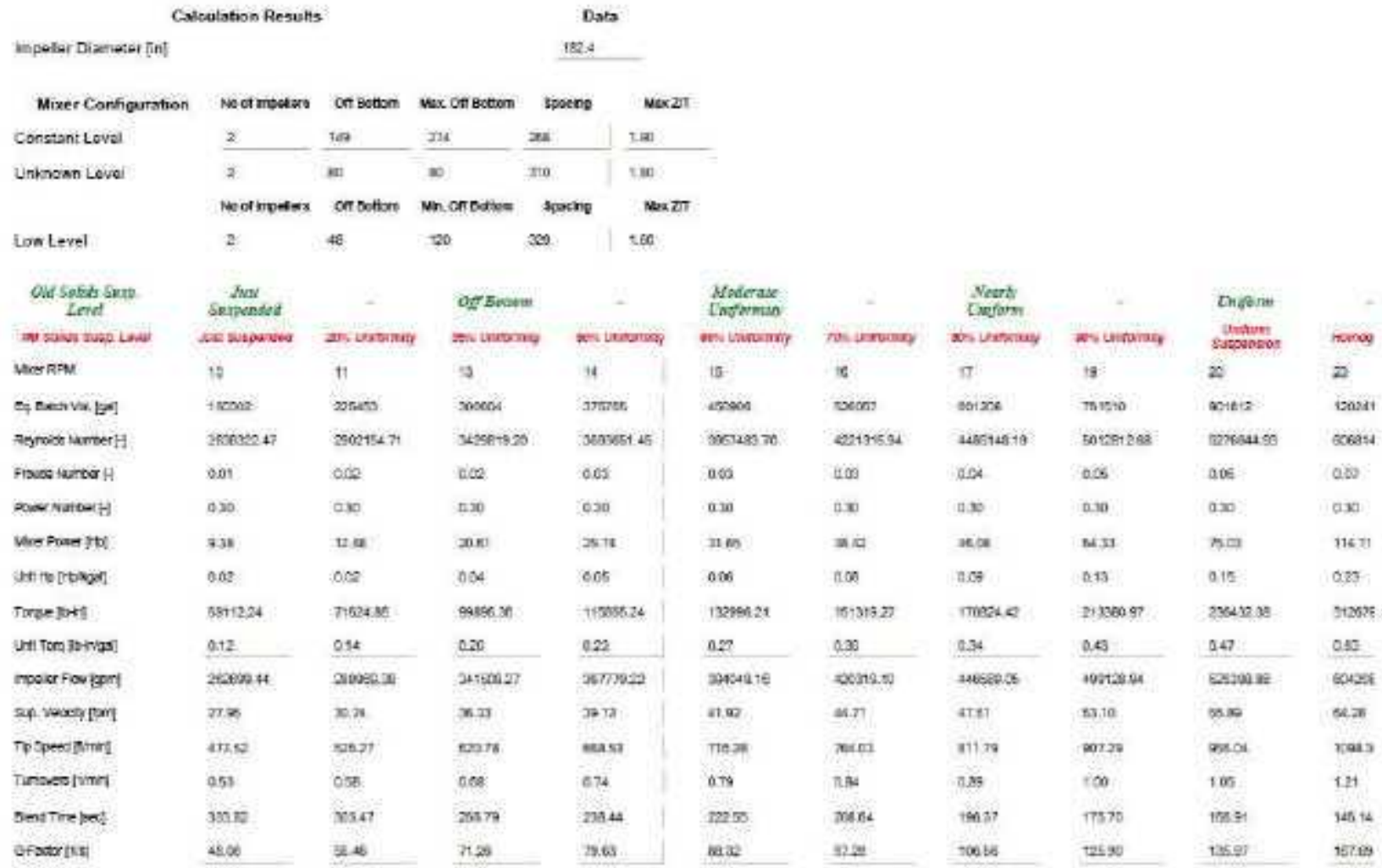


Figure B-2 PMSL recommended vessel geometry

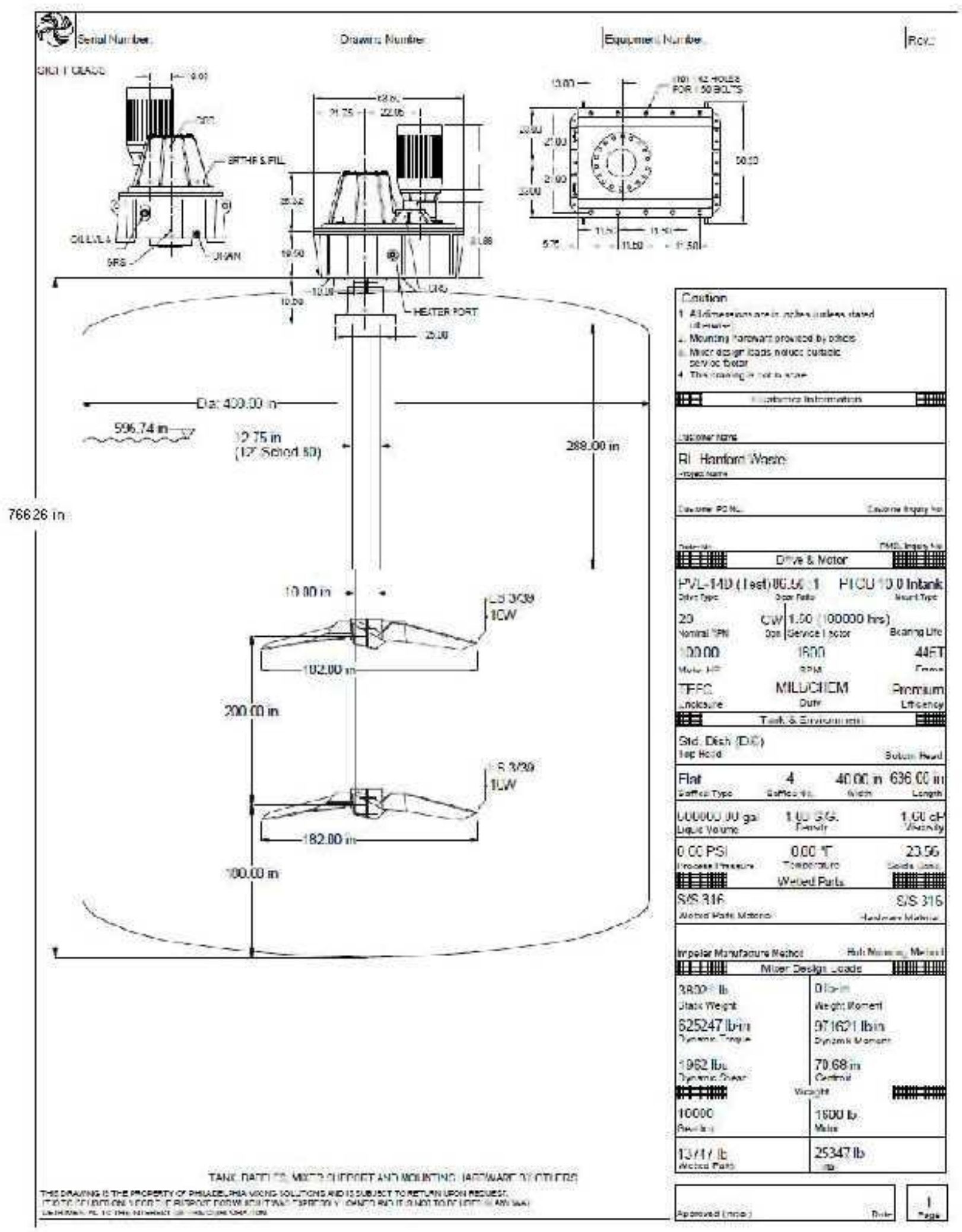


RPP-RPT-42527, Rev, 0

APPENDIX C

UNPUBLISHED REFERENCE MATERIAL 


\section{Presentation}

Presentation Date: January 20-22, 2009

Presenter: A. Etchells

Scope of Presentation: Solids-Liquids Mixing

2.2 Semi-empirical correlation by Zwietering

$$
N_{J S}=s v^{0.1}\left(\frac{g \Delta \rho}{\rho_{L}}\right)^{0.45} X^{0.13} d p^{0.2} D^{-0.85}
$$

No solids remain at the vessel base for more than 1 -to-2 seconds

Extensive data sets can be correlated

Some theoretical justification

\section{Limitations and applicability}

- " $\mathrm{s}$ " values have to be known

- Characteristic of geometry only - maybe

- not applicable outside the experimental conditions

- applies to free and hindered settling conditions (i.e. low to moderate $\mathrm{X}$ ), $\mathrm{X}$ is weight of solids divided by weight of liquid times 100 - UGH

but may not be valid or relevant in significantly non-Newtonian systems (i.e. at high $\mathrm{X}$ ) 


\section{Presentation}

Continued from page C-2

Table 1. Gentnetrical constant, in values for three

different impeller types in a flat base vessel.

\begin{tabular}{|c|c|c|c|c|c|}
\hline \multicolumn{2}{|c|}{$\begin{array}{c}\text { s values at CIT } \\
=\end{array}$} & $1 / 3$ & $1 / 4$ & $1 / 6$ & $1 / 8$ \\
\hline \multirow[t]{2}{*}{ RDT } & $\begin{array}{l}\mathrm{D}= \\
\mathrm{T} / 2\end{array}$ & 4.72 & 4.2 & 3.67 & 3.41 \\
\hline & $\begin{array}{l}\mathrm{D}= \\
\mathrm{T} / 3\end{array}$ & 8.33 & 7.43 & 6.50 & 603 \\
\hline \multirow[t]{2}{*}{ PBT4-45 } & $\begin{array}{l}D= \\
T / 2\end{array}$ & 4.97 & 474 & 4.52 & 4.40 \\
\hline & $\begin{array}{l}\mathrm{D}= \\
\mathrm{T} / 3\end{array}$ & 6.95 & 6.64 & 6.32 & 6.16 \\
\hline \multirow[t]{2}{*}{ HE-3 } & $\begin{array}{l}\mathrm{D}= \\
\mathrm{T} / 2\end{array}$ & 7.14 & 6.82 & 6.50 & 6.35 \\
\hline & $\begin{array}{l}\mathrm{D}= \\
\mathrm{T} / 3\end{array}$ & 20.41 & 995 & 9.48 & 925 \\
\hline
\end{tabular}

Table 2. Operating conditions over which Zwietering's correlation is obtained

\begin{tabular}{|c|c|}
\hline Parameter & Ranqe covered \\
\hline$\Delta \rho\left(\mathrm{kg} / \mathrm{m}^{3}\right)$ & $560-1800$ \\
\hline$d_{p}(\mu \mathrm{m})$ & $140-520$ \\
\hline$X(\%)$ & $0.5-20$ \\
\hline$T(\mathrm{~m})$ & $0.1-0.6$ \\
\hline$D / T$ & $1 / 6-1 / 2$ \\
\hline$n_{b}$ & 4 \\
\hline$C / T$ & $1 / 20-1 / 2$ \\
\hline Impel. type & 4 \\
\hline $\begin{array}{c}\text { Vessel base } \\
\text { shape }\end{array}$ & $\begin{array}{c}\text { Flat, dish \& } \\
\text { conical }\end{array}$ \\
\hline$\mu_{L}$ (mPa s) & $0.3-9$ \\
\hline
\end{tabular}




\section{Presentation}

Continued from page $\mathrm{C}-3$

\section{Z CORRELATION}

- Since has been extended to many more geometries and sizes and densities

- Not perfect but conservative and nothing better

\section{Main Findings}

- Impeller Geometry

- Axial flow impellers (e.g. hydrofoils) pumping downwards are the most energy efficient; radial flow (e.g. 6DT) and saw tooth impellers are the least energy efficient for off-bottom suspension.

- Low C generally more energy efficient, except at extremes (e.g. $\mathrm{D} / \mathrm{T}>0.5 \mathrm{C} / \mathrm{T}<1 / 6$ )

- Low liquid heights - starve impeller 
RPP-RPT-42527, Rev. 0

\section{Presentation}

Presentation Date: June 2, 2009

Presenter: Perry Meyer

Scope of Presentation: Jet Mixing Experience at PNNL

\section{Test Scales}

Choosing scales needs to be supported by some analysis

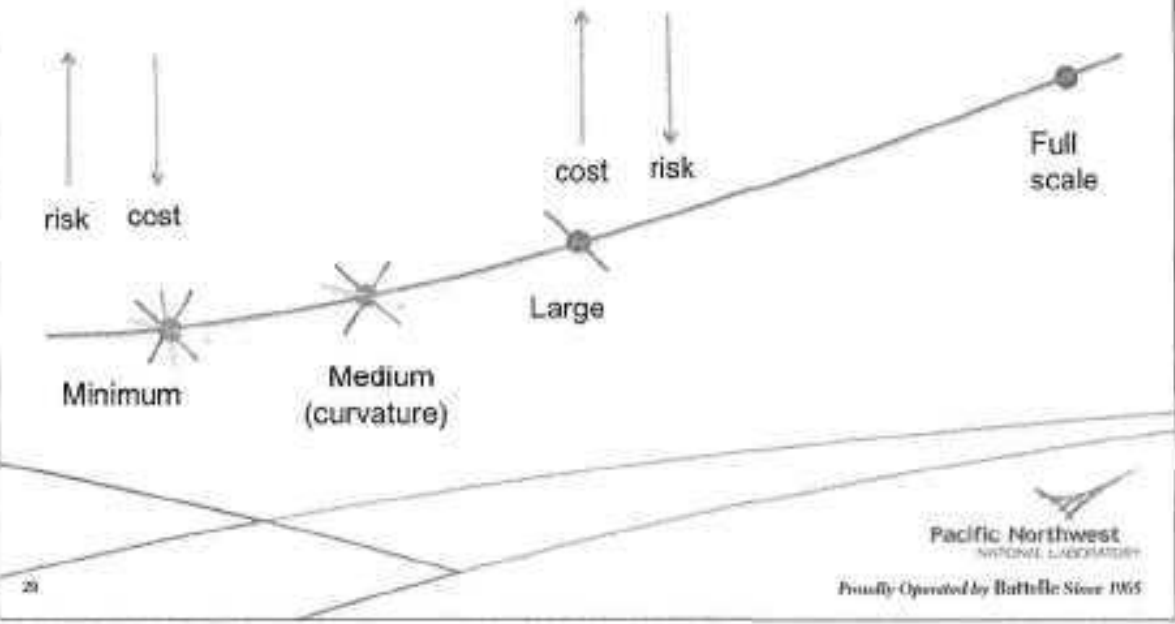

\section{CFD}

- Useful, but existing software with simplified physics are limited

- Must be incrementally validated

> Never assume CFD does anything "easy" e.g. scale-up

- Should coordinate tests with CFD development \& validation effort

> Transformational Jump in CFD Capability Needed

$$
\text { " Predictive Process Science }
$$

- EM-21 Initiative: Modeling and Simulation in Nuclear Process Science

" Late 2009 start

a Will use data from Hanford tests (simulants) for validation

- Wil focus on development $\&$ application

- Wil utilize High Performance Computing as appropriate

- Team: Multi-Lab + Universities + Competitive Procurement

in Goals

- Enable technology selection

- Guide and maximize value of scaled testing

- Support plant design and construction

- Optimized plant operations 
RPP-RPT-42527, Rev. 0

\section{Email Correspondence}

Originator: P.W Griffin

Correspondent: D.S. Dickey

\section{Griffin, Peter W}

From:

Sent:

To:

Subject:
David Dickey [d.dickey@mixtech com]

Wednesday, May 20, 2009 7:58 AM

Griffin, Peter W

$\mathrm{Re}$ : Zwietering

Peter,

Your starting point should be Chapter 10 Solid-Liquid Mixing in the Incustrial Mixing Handbook, John Wiey \& Sons 2004. I cannot remember what has been published about agitation intensity for "uniform" suspension, since "uniform" rarely happens for setting particles. The power number should not change for solids suspension, although the power should be proportional to slurry density for turbulent suspension.

The test apparatus should be as large as practical and small enough to study and modify. The most important factor is geometric similarity. Usually the tank geometry has practical limits for modeling, either the mixing device of the tank internals. For large tanks, my experience has been that less than 1 meter diameter is probably too small for good test results. Larger than 2 meters becomes more difficult to do experimental work and observe the results or chance conditions easily. Multiple impellers are covered in the Handbook chapter, but the simple answer is that only the lower impeller has any significant effect on off-bottom suspension. An upper impeller may improve suspension uniformity.

Dave

David S. Dickey, Ph.D.

MixTech, Inc.

454 Ramsgate Drive

Dayton, $\mathrm{OH} 45430-2097$

Phone: $937-431-1446$

Fax: 937-431-1447

d.dickey@mixtech.com

www.mixtech.com

- Original Message -...

From: Griffin, Peter W

To: 'David Dickey

Sent: Wednesday, May 20, 2009 10:41 AM

Subject: RE: Zwietering

Dave,

Thanks for the information. Is there a text or source you would recommend regarding projected increases in agitator intensity and power number to move from just-suspended regime to uniform suspension? Or is this one of those areas where correlations can't be found? Also, if I were to do a test (which seems very likely) is there a certain volume range that I should look into for a test apparatus that will decently represent such a large tank? My goal being that I don't want to develop equipment based around a test apparatus that was too small.

Lastly, any texts or insights on predicting speed, power, etc... when multiple impellers are used?

Thanks,

Peter Griffin 
RPP-RPT-42527, Rev. 0

\title{
Email Correspondence
}

\author{
Originator: P.W Griffin
}

Correspondent: G.B. Tatterson

\section{Griffin, Peter W}

\begin{tabular}{|c|c|}
\hline $\begin{array}{l}\text { From: } \\
\text { Sent: } \\
\text { To: } \\
\text { Subject: }\end{array}$ & $\begin{array}{l}\text { G8T [got@encat,edu] } \\
\text { Tuesday, May 26, } 20095.08 \text { AM } \\
\text { Griffin, Peter W } \\
\text { Re: Solid Suapension }\end{array}$ \\
\hline Peter, & \\
\hline
\end{tabular}

height near the impeller, baffle number, etc.

Power number (standard geometry) for pitched blade turbines, 4 blades 45 degree pitch, is 1.26; hydrofoils 0.6 . If they are spaced apart in a reasonable fastion, the power is propontional to impeller number. If the impellers are placed upon each other, the power number would vary between that of a single impeller and that of two impeliers.

You can purchase my book from Amazon.com. There you can find all sorts of information and details on power.

Baffles affect power because they affect the impeller drag. However, in a very large tank, the baffle effect may be less. When you are large scale, the process changes. The problem is: "What does it change to?"

What is the diameter of 500,000 gals? I assume you are mounting the impeller along the centerline. Correct?

Of course, you should realize that there is no connection between power and mixing. You can mix at very low power. Solid suspension is different.

If you can't reach me in my office, my home phone is 336-882-4737. You can call anytime, except I may be out cutting the grass or gardening. Evening EST might be a good time.

Good Luck,

Gary Tatterson

\footnotetext{
-... Original Message -..-

From: Griffin, Peter W

To: 'GBT

Sent: Thursday, May 21, 2009 1:33 PM

Subject: RE: Solid Suspension

Gary.

I really appreciate the information.

You assumed right-l'm planning on using impellers.

I $\mathrm{m}$ afreid I missed my window of opportunity to call you today, but if time allows, I may try to reach you tomorrow.

In the mean time, perhaps you can answer another question-1 was planning to use 4 baffles on the tank walls to promote mixing. I've been using the $P=P \circ N^{\wedge} 3 D^{\wedge} 5$ correlation to estimate the power. It is my guess that the addition of
} 
RPP-RPT-42527, Rev. 0

\section{Email Correspondence}

\section{Continued from page $\mathrm{C}-7$}

baffles and multipie impellers will cause a power increase. My questian is, is this power increase reflected by the power number, $P_{0}$ ? In other words, are there Ponumbers that account for multiple impellers and baffles?

Thanks again,

Peter

From: GBT [mailto:gbtincat.edu]

Sent: Thursday, May 21, 2009 8:03 AM

To: Griffin, Peter W

Subject: Solid Suspension

Peter,

Are you using an impeller or pulse jet mixers? I guess an impeller from your question. In either case cata are available to answer some of your questions.

Zwietering published his correlation in 1956 (or 1957?) - a long time ago.

Limitations of the Zwietering correlation for suspending solids in liquids are many. His paper reduces to a constant for various impelers:

For very large tanks, say 500,000 gallons, I suspect centered mounted impellers don't suspend very well - lots of sand dunes at the walls. The tank bottom will be determined by the solids. Tanks are contoured by the process itself or are made that way. I would expect side-entering jets will help.

Most everything is controlled by geometry. If you get the geometry right, then everything goes well. If not, then you have job security because of all the problems you will experence. If you use impellers, I would recommend a down pumping hydrofoil impeller $1 / 3$ off the bottom with another up-pumping hydrofoil mounted on the same shaft $2 / 3$ off the bottom. The botiom impeller swepts the bottom. The top impeller carries the material up into the top portion of the tank. Adding in supporting side-entering bottom jets pointed in the right direction, you might have a fantastic geometry. This ceometry is not discussed in the literature but comes to me from a lawsuit that BHP filed against Lightning Mixing Company for a slurry tank which fed a pipeline.

"How to determine a reprosentative mcan particle diameter (and density) in a substance where it can vary dramatically, I would forget the small stuff and focus on the larger and heavier particles. If you can handle the big ones then the small stuff tags along free.

Attached some articles which can help you.

As you will find out, you can approach uniformity when $Z / T$ is 1.0 at high modified Froude numbers.

My number is 336-334-7564 $\times 320$. You can call about 11:00AM EST if you like.

Good Luck,

Gary Tatterson

- Original Message ....

From: Griffin. Peter W

To: 'abt@ncatedu'

Sent: Wednesday, May 20, 2009 1:17 PM

Subject: Zwietering Correlation Question 


\section{Email Correspondence}

\section{Continued from page C-8}

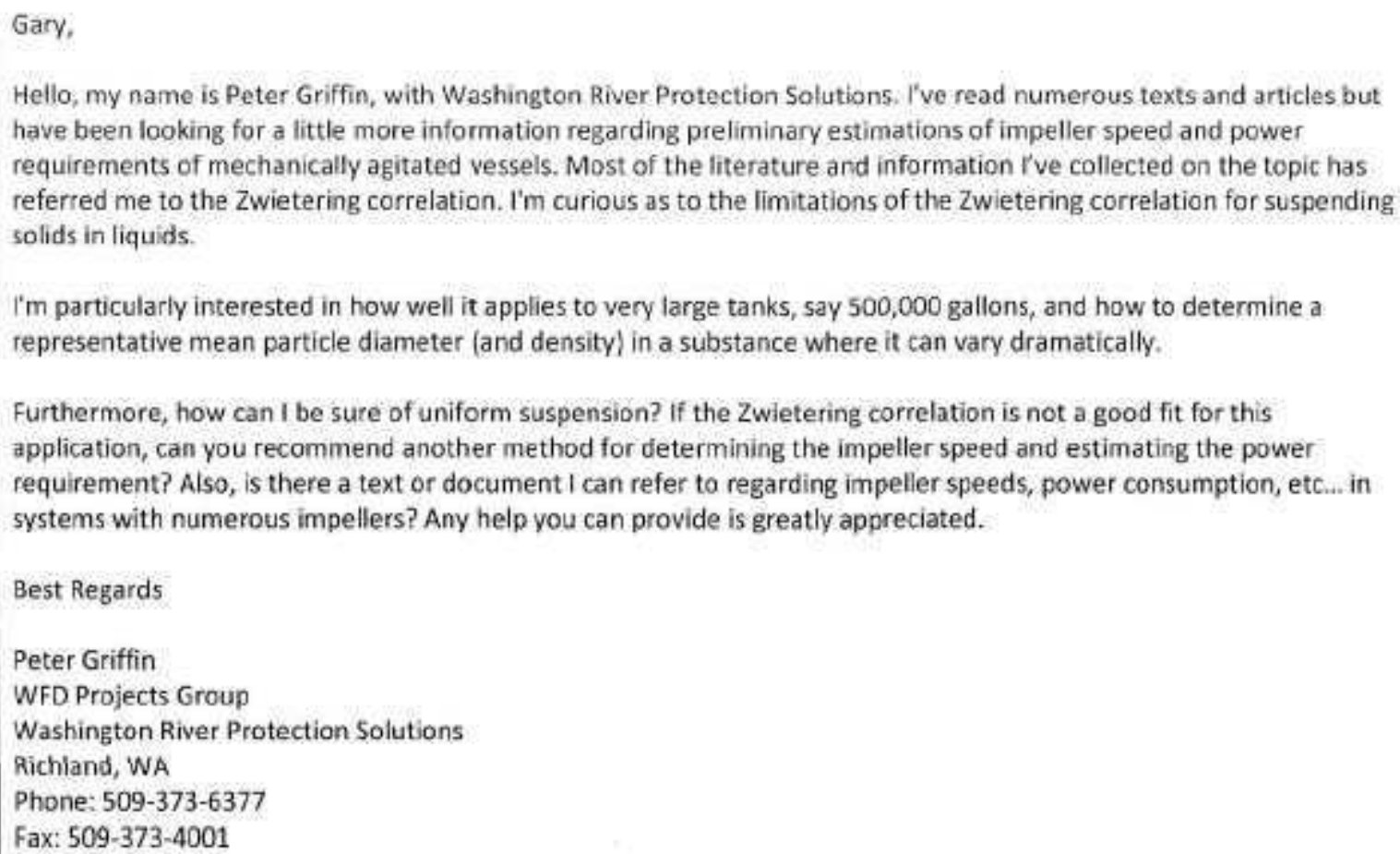


RPP-RPT-42527, Rev, 0

\section{Griffin, Peter W}

$\begin{array}{ll}\text { From: } & \text { Todd Hutchinson [THUTCHINSON@philadelphiamixers.com] } \\ \text { Sent: } & \text { Friday, August 07, 2009 11:18 AM } \\ \text { To: } & \text { Griffin, Peter W } \\ \text { Cc: } & \text { Darrell Thatcher; Steven Barnak; John Reilly } \\ \text { Subject: } & \text { RE: Thank you }\end{array}$

Peter.

As a follow up to our phone conversation on Wednesday the program used to generate the different levels of solids suspension is a Philadelphia Mixing Solutions written program that is based on a Torquelunit-volume approach for suspending solids. This approach has been used to successfully design 40,000 plus mixers that perform solid suspension duties. Most applicable to your application would be the mixers we supplied to IHI's Japanese WTP, the Oak Rdgo, TN site, and Savannah River as well as the (8) LAW mixers and (4) HLW mixers for the Bechtel WTP. All of these mixers were reduced scale model tested using customer specified simulate to confirm the program sizing. In some of the Savannah Fiver applications PMSL performed full scale testing.

As you are aware the Bechtel LAW and HLW mixers have not been started up yet however the Catholic University located outside of Washington, DC has preformed full scale performance work with the LAW/HLW designs. They could be consulted for acceptance.

There are various published procedures for sizing mixers for solids suspension. We have found our procedure generates very acceptable results confirmed by our lab lesting and the fact that we do not have any warranty claims against solid suspension performance issues. Dr. Arthur W. Etchells III could also be contacted as a reference. He does not specifically use our procedure but he has witnessed the results of the sizing using our procedure in our laboratory.

\section{Sincerely.}

Todd M. Hutchinson

GM Advanced Solutions Engineering Division

Philadelphia Mixing Solutions, Ltd 